Ortaköylü, S., Satılmış, S. ve Eyüp B. (2020). Yurt dışında yaşayan Türk çocuklarına yönelik yapılan araştırmalar üzerine bir analiz çalışması. Ana Dili Eğitimi Dergisi, 8(1), 87-112.

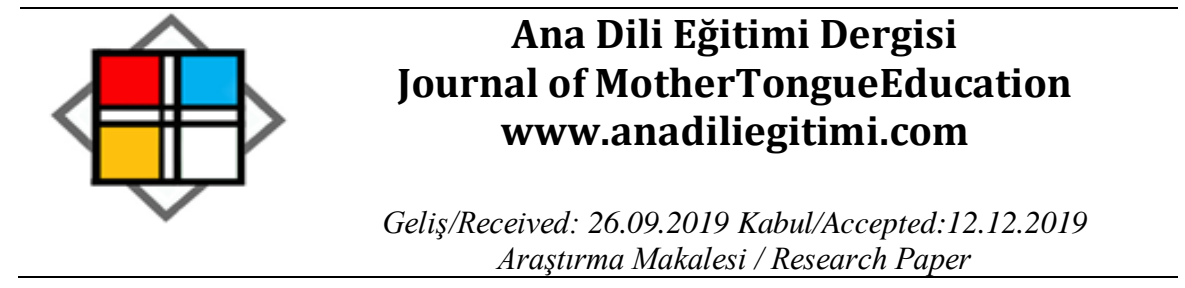

\title{
Yurt Dışında Yaşayan Türk Çocuklarına Yönelik Yapılan Araştırmalar Üzerine Bir Analiz Çalışması
}

\author{
Seçil ORTAKÖYLÜ* \\ Sinem SATILMIŞ** \\ Bircan EYÜP ${ }^{* * *}$
}

\begin{abstract}
Öz
Bu çalışmanın amacı, yurt dışında yaşayan Türk çocuklarını dil açısından ele alan 2000-2018 yılları arasında yapılmış olan çalışmaların içerik analizini yapmak ve araştırma eğilimlerini belirlemektir. Çalışma nitel araştırma modeline göre yürütülmüştür. Yapılan incelemelerde, konuyla ilgili TRDizinde taranan dergilerde yayımlanmış 19 makale ve YÖK Ulusal Tez Merkezinden belirlenen 18 lisansüstü tezi olmak üzere toplam 37 çalışmaya ulaşılmıştır. Veriler içerik analizi ile incelenmiştir. Makale ve tezler; yayın yılı, anahtar kelimeler, konu, örneklem, örneklemin seçildiği ülke, yöntem, veri toplama araçları, sonuçlar ve öneriler konularında analiz edilmiştir. Konuyla ilgili az sayıda çalışmanın yapıldığı belirlenmiştir. Çalışmaların çoğunda Türk nüfusunun yoğun olduğu Avrupa ülkelerinde yaşayan Türk çocukları üzerine yoğunlaşıldığı, en fazla tercih edilen anahtar kelimelerin ana dili ve iki dillilik olduğu tespit edilmiştir. Çalışmaların genellikle dil becerilerine yönelik yapıldığı, nitel yöntemin ağılıklı olarak kullanıldığı, veri toplama aracı olarak en fazla anket/ölçeğin tercih edildiği belirlenmiştir. Çalışmalarda en fazla ailenin özelliklerinin dil becerilerini etkilediği sonucuna ulaşıırken, en fazla önerinin de hükümetlere yönelik olduğu tespit edilmiştir.
\end{abstract}

Anahtar Kelimeler: íki dillilik, yurt dışında yaşayan Türk çocukları, ana dili, Türkçe öğretimi.

\begin{abstract}
This study aims to analyze the studies conducted between the years 2000-2018 on Turkish children living abroad in terms of language development and to determine the research trends that observed in those studies by doing content analysis. The study is qualitative in design. In the analysis it was determined that there was a total of 37 studies, 19 of which were articles published in journals indexed in the TR-index and 18 of which were Master's theses and doctoral dissertations that were available in the Higher Education Council National Dissertation Center. The data were analyzed using content analysis. The articles and theses were analyzed in terms of their years of publication, keywords, subjects, samples, countries, method, data collection tools, results, and recommendations. It was found that there were very few studies on the subject. It was determined that most of the studies focused on Turkish children living in European countries in which there were dense Turkish populations and that the mostly preferred keywords were mother tongue and bilingualism. It was also found that the studies generally focused on language skills, that qualitative method was used predominantly and questionnaire was the most preferred data collection tool in both articles and theses. The most common result in the studies was that
\end{abstract}

An Analysis of Research Studies on Turkish Children Living Abroad

\footnotetext{
* Türkçe Öğretmeni, Millî Eğitim Bakanlığı, Rize, secil.ortakoylu@gmail.com, ORCID: 0000-0003-2321-2084

${ }^{* *}$ Yüksek Lisans Öğrencisi, Trabzon Üniversitesi, Fatih Eğitim Fakültesi, Türkçe ve Sosyal Bilimler Eğitimi Bölümü, Trabzon, sinemstlm.8@gmail.com, ORCID:0000-0001-8054-2069

${ }^{* * *}$ Dr. Öğr. Üyesi, Trabzon Üniversitesi, Fatih Eğitim Fakültesi, Türkçe ve Sosyal Bilimler Eğitimi Bölümü, Trabzon, bircaneyp@gmaıl.com, ORCID: 0000-0001-8061-1159
} 
the characteristics of the families affected language skills and most of the recommendations were made for governments.

Keywords: Bilingualism, Turkish children living abroad, mother tongue, Turkish education.

\section{Giriş}

Dili; düşünce, duygu ve isteklerin, bir toplumda ses ve anlam yönünden ortak olan ögeler ve kurallardan faydalanılarak çevredekilere aktarılmasını sağlayan, çok yönlü, gelişmiş bir dizge olarak tanımlamak mümkündür (Aksan, 2009: 55). Başkan (2003: 87) ise dilin bir toplulukta, insanların birbirleri ile karşılıklı olarak anlaşmalarını sağlayan, göstergeler ve kurallar bütününden oluşan bir bildirişim düzeneği olduğunu ifade eder. Dil, genel anlamda insanlar arasında anlaşmayı sağlayan bir vasıta olarak tanımlanmaktadır.

Milletin kimliği, var olma sebebi, olmazsa olmazı, şerefi olarak dil önemli bir yere sahiptir. Dile dayalı bu beraberlik, hayatın başka unsurlarıyla birlikte kültürü meydana getirse de dil daima pratik ve en doğal haliyle bir anlaşma ve iletişim aracı olarak ilk işlevini yerine getirmiştir. Bugün de insan, yeni doğan, çocuk ya da yetişkin fark etmeksizin her şeyden önce bir iletişim ve anlaşma ihtiyacıyla dili kullanır. Toplumlar da ortaklıkları ve iletişim ihtiyaçlarıyla bir dil edinmişler ve yeni doğan bireylere bu dili aktararak yaşatmaya devam etmişlerdir. Bu aktardıkları ve yaşattıkları dil, insanların içinde doğdukları ve büyüdükleri ortamın dili olarak, çevrelerinde ilk önce ve en çok "ana" bulunduğu için de "ana dili" olarak isimlendirilmiştir (Kırımlı, 2017).

Dilin ve eğitim-öğretimin yanı sıra psikolojik, sosyolojik, etnik ve siyasal bağlamlarda da ele alınan, tartışılan bir kavram olan ve bireyin dünyaya gelişiyle içerisine dâhil olduğu sosyal çevrede edindiği ilk dili veya ana dili farkı şekillerde tanımlanmıştır. Türkçe Sözlük'te (2011), "Çocuğun ailesinden ve içinde yaşadığı topluluktan edindiği dil." olarak tanımlanan ana dilini, Aksan (2014: 175) ise "Başlangıçta anneden ve yakın aile çevresinden, daha sonra ilişkili bulunulan çevrelerden öğrenilen, insanın bilinçaltına inen ve bireyin toplumla en güçlü bağlarını oluşturan dildir." şeklinde tarif etmiştir. Vardar (1998: 20) ise "İnsanın içinde doğup büyüdüğü aile ya da toplum çevresinde ilk öğrendiği dil." şeklindeki tanımıyla dilin sosyal yönünü oluşturan çevreye vurgu yapmıştır. Ancak günümüzde bireyler ana diliyle başladığı dil öğrenme sürecinde zaman içerisinde farklı dilleri de öğrenme durumunda kalmaktadır. Özellikle de dünyada meydana gelen olaylarla (savaş, toplu göç, ülkeler arası birlikler -AB- gibi) ve bireylerin tercihleriyle (eğitim, evlilik, bireysel göç gibi) birlikte iki dillilik, ülkelerde gitgide artmaktadır (Şen,2016). Baker'a (2007) göre birden fazla dil kullananlar dünyadaki çoğunluğun büyük bir kısmını oluşturmaktadır. Hemen her ülkede birden fazla dil konuşulduğundan dünya genelinde iki ve çok dilli bireylere sıkça rastlanması mümkün hâle gelmiştir.

İki dillilik kavramı W. Field tarafından "Genel olarak iki dile sahip olma, iki dille konuşma ya da iki dilli olma durumudur." (2011: 22) şeklinde nicel yönüne vurgu yapılarak sınırlı bir anlamla tanımlansa da iki dillilik kavramının literatürde hem iki dilliliği hem de çok dilliliği karşılayacak şekilde kullanıldığı ortadadır. Bugün benimsenen tanıma göre bireyin iki dilli sayılabilmesi için o kişinin günlük yaşantısında kullandığı tüm dillerde aynı seviyede performans göstermesi beklenmemektedir (Baker, 1988; Baker ve Jones, 1998; Baker, 2011; Bhatia ve Ritchie, 2006; Yılmaz, 2014). Birey tüm dillerde farklı seviyelerde yeterliliğe sahip olup gündelik hayatında da bu dilleri kullanıyorsa iki dilli sayılmaktadır.

Geçmişten beri insanlar, topluluklar çeşitli sebeplerden dolayı vatanlarından göç etmek durumunda kalmışlardır. Türkler de tarih boyunca farklı sebeplerden ötürü göç etmiş ya da ettirilmiştir. Başta Avrupa ülkeleri olmak üzere günümüzde pek çok ülkede iş sebebiyle, politik sebeplerle ya da farklı amaçlarla göç etmiş Türkler yaşamaktadır. 2018 yılı Türkiye İstatistik Kurumu verilerine bakıldığında yurt dışında yaşayan Türklerin sayısı 6 milyonun üzerindedir. Bu oranın önemli bir kısmını da çocuklar oluşturmaktadır (http2). Genellikle iki dilli yetişen bu çocuklar, çoğu zaman evleriyle okul ortamları arasında bambaşka iki dilin ve kültürün etkisinde anlamaya ve anlatmaya, kendilerini ifade etmeye çalışmaktadırlar. Bu durumun çocuklar üzerinde fizyolojik, bilişsel, psikolojik ve sosyolojik açıdan olumlu veya olumsuz ne tür etkilere ve değişimlere yol açtığı önemli sorular arasındadır. Bu sorular ve benzer birçok soru üzerine yapılan her araştırma, elde edilen her sonuç ve çözüm önerisi yurt dışında yaşayan Türk çocuklarını daha iyi anlamak ve gelişimlerine olumlu yönde 
katkı sağlamak adına önem taşımaktadır. Bu nedenle bu alanda yapılmış araştırmaları bilmek, başka ne yapılabileceğine dair bir fikir oluşması açısından önemlidir. Bu doğrultuda, bu araştırmada yurt dışında yaşayan Türk çocuklarını dil açısından ele alan alanyazında yapılmış olan araştırmaları toplu bir şekilde sunmak amaçlanmıştır.

Bu araştırmada, yurt dışında yaşayan Türk çocuklarını dil açısından ele alan araştırmaları toplu bir şekilde sunmak amacıyla aşağıdaki alt problemlere cevaplar aranmıştır:

1. Yurt dışında yaşayan Türk çocukları hakkında yapılmış çalışmaların yıllara göre dağıımı nasıldır?

2. Yurt dışında yaşayan Türk çocukları hakkında yapılmış çalışmaların anahtar kelimelerinin dağılımı nasıldır?

3. Yurt dışında yaşayan Türk çocukları hakkında yapılmış çalışmaların konu dağııımı nasııldır?

4. Yurt dışında yaşayan Türk çocukları hakkında yapılmış çalışmaların örneklem türüne göre dağılımı nasıldır?

5. Yurt dışında yaşayan Türk çocukları hakkında yapılmış çalışmaların ülkelere göre dağılımı nasıldır?

6. Yurt dışında yaşayan Türk çocukları hakkında yapılmış çalışmaların kullandıkları yönteme göre dağııımı nasıldır?

7. Yurt dışında yaşayan Türk çocukları hakkında yapılmış çalışmalar hangi veri toplama araçlarından faydalanmıştır?

8. Yurt dışında yaşayan Türk çocukları hakkında yapılmış çalışmalardan elde edilen sonuçlar nelerdir?

9. Yurt dışında yaşayan Türk çocukları hakkında yapılmış çalışmalar sonucunda hangi önerilerde bulunulmuştur?

\section{Araştırmanın Modeli}

\section{Yöntem}

Bu çalışma, nitel araştırma modeline göre yürütülmüştür. Nitel araştırmaların en temel özelliği, üzerinde araştırma yapılan kişilerin bakış açılarıyla araştırılan olay, olgu, norm ve değerleri incelemeye çalışmasıdır (Ekiz, 2017: 31). Bu çalışmada da yurt dışında yaşayan Türk çocukların diline, kültürüne ve eğitimine yönelik yapılmış akademik çalışmaların incelenmesi amaçlanmıştır. Bu doğrultuda çalışma için gerekli olan verilerin toplanması nitel araştırma yöntemlerinden doküman incelemesi ile gerçekleştirilmiştir. Doküman incelemesi, araştırılması hedeflenen olgu veya olgular hakkında bilgi içeren yazılı materyallerin analizini kapsar (Yıldırım ve Şimşek, 2008: 189).

\section{İncelenen Dokümanlar}

Bu çalışmada, yurt dışında yaşayan Türk çocukları üzerine 2000-2018 yılları arasında yapılmış olup YÖK Ulusal Tez Merkezinden "iki dillilik, iki dilli, ana dili, ana dil, yurt dışında yaşayan Türk çocukları, Türkçe eğitimi, Türkçe öğretimi, ana dil öğretimi, iki dilli eğitim, yurt dışında yaşayan Türk çocuklarının dil kazanımı" anahtar kelimeleri ile yapılan taramalar sonucu konuyla ilgili olan 9 yüksek lisans tezi ve 10 doktora tezi olmak üzere toplamda 19 tez ve ULAKBiM TR-Dizinde taranan, adında 'sosyal, eğitim ve dil' kelimelerinden en az biri bulunan dergilerden tespit edilen 19 makale bu çalışma kapsamına alınmıştır. Ancak 2016 yılında yapılmış olan bir yüksek lisans tezine ulaşılamadığı için tam metnine ulaşılabilen 18 tez ve 19 makale bu çalışmada ele alınmıştır. Araştırma çerçevesinde incelenen makalelerin yayımlandıkları kaynağa ve yıllara göre frekans dağılımı Tablo 1'de sunulmuştur. 
Tablo 1.

Araştırma çerçevesinde incelenen makalelerin yayınlandıkları kaynağa göre frekans dağılımı

Makalelerin Alındığı Kaynaklar $\quad f \quad f \quad f \quad f \quad f \quad f \quad f \quad f \quad f \quad f \quad f$

\begin{tabular}{|c|c|c|c|c|c|c|c|c|c|c|c|}
\hline Abant İzzet Baysal Ünv. Eğitim Fak. Dergisi & 1 & & & & & & & & & & \\
\hline Adıyaman Ünv. Sosyal Bilimler Enstitü Dergisi & & & & & & 1 & & & & & \\
\hline Ana Dili Eğitimi Dergisi & & & & & & & & & & & 2 \\
\hline Bartın Ünv. Eğitim Fak. Dergisi & & & & & & & & & 1 & & \\
\hline Bilig & & & & 1 & & & 1 & & & & \\
\hline Eğitim ve Bilim & & & & & & & & & & & 1 \\
\hline Karadeniz Sosyal Bilimler Dergisi & & & & & & & & 1 & & & \\
\hline Kastamonu Ünv. Kastamonu Eğitim Dergisi & & & & & & & & & & 1 & \\
\hline M.Ü. Atatürk Eğitim Fak. Eğitim Bilimleri Dergisi & & 1 & & & & & & & 1 & & \\
\hline Mehmet Akif Ersoy Ünv. Eğitim Fak. Dergisi & & & & & 1 & & & & & & \\
\hline Millî Eğitim Dergisi & & & & 1 & & & 1 & & & & \\
\hline Ondokuz Mayıs Ünv. Eğitim Fak. Dergisi & & & & & & & & & 1 & & \\
\hline Selçuk Ünv. Sosyal Bilimler Enstitüsü Dergisi & & & 1 & & & & & & & & \\
\hline Sosyal Politika Çalışmaları Dergisi & & & & & & & 1 & & & & \\
\hline Uludağ Ünv. Eğitim Fak. Dergisi & & & & & & & & & & & 1 \\
\hline TOPLAM & 1 & 1 & 1 & 2 & 1 & 1 & 3 & 1 & 3 & 1 & 4 \\
\hline
\end{tabular}

Araştırma çerçevesinde incelenen lisansüstü tezlerin yapıldıkları üniversitelere ve yıllara göre frekans dağılımı Tablo 2'de sunulmuştur.

Tablo 2.

Araştırmaçerçevesinde incelenen lisansüstü tezlerin yapıldığı üniversitelere göre frekans dağılımı

\begin{tabular}{llccc}
\hline \multirow{2}{*}{ Üniversite Adı } & \multicolumn{2}{c}{ Yüksek Lisans } & \multicolumn{2}{c}{ Doktora } \\
\cline { 2 - 5 } & $f$ & 55.5 & $f$ & 4 \\
\hline Gazi Üniversitesi & 5 & 11.1 & - & - \\
\hline Çukurova Üniversitesi & 1 & 11.1 & - & - \\
\hline Anadolu Üniversitesi & 1 & 11.1 & - & - \\
\hline Sakarya Üniversitesi & 1 & 11.1 & - & - \\
\hline Bolu Abant İzzet Baysal & 1 & - & 1 & 11.1 \\
\hline Çanakkale Onsekiz Mart & - & - & 1 & 11.1 \\
Ü. & - & - & 1 & 11.1 \\
\hline Eskişehir Osmangazi Ü. & - & - & 1 & 11.1 \\
\hline Ankara Üniversitesi & - & - & 1 & 11.1 \\
\hline İstanbul Üniversitesi & - & 100 & 9 & 100 \\
\hline Atatürk Üniversitesi & 9 & & & \\
\hline Toplam & & & & \\
\hline
\end{tabular}

\section{Verilerin Toplanması ve Analizi}

Araştırma konusuyla ilgili 2000-2018 yılları arasında yapılmış olan lisansüstü tezlerin tespit edilmesi için YÖK Ulusal Tez Merkezinde tezler araştırmacılar tarafından ayrı ayrı taranmıştır. Tarama işlemi sonunda konuyla ilgili toplam 19 teze ulaşılmıştır. Ancak bu tezlerden ikisinin tam metnine ulaşılamamıştır. Tam metnine ulaşılamayan iki tez için söz konusu araştırmaların yazarlarına ulaşılmaya çalışılmıştır. Tezlerden biri elde edilirken diğer tezin araştırmacısına ulaşılamadığından çalışmaya dâhil edilmemiştir. Araştırmanın makale tarama kısmında ise ULAKBiM Tr-Dizinde adında 
"eğitim", "sosyal" ve "dil" geçen dergiler Nisan-Mayıs aylarında belirlenmiştir. Daha sonra bu dergilerin 2000-2018 yıllarındaki sayıları tek tek taranmış ve araştırma konusu ile ilgili olan makaleler seçilerek çalışmaya dâhil edilmiştir.

Çalışmada elde edilen veriler içerik analizi tekniği ile incelenmiştir. 2000 ve 2018 yılları arasında yapılan tezler ve makaleler dokuz temel kategori altında analiz edilmiştir. İçerik analizinde yapılan işlem, toplanan verileri açıklayabilecek kavramlara ve ilişkilere ulaşmaktır. İçerik analizi ile veriler tanımlanmaya çalışılır ve verilerin içinde saklı olabilecek gerçekler ortaya çıkarılır. İçerik analizinde temelde yapılan işlem, birbirine benzeyen verileri belirli kavramlar ve temalar çerçevesinde bir araya getirmek ve bunları okuyucunun anlayabileceği bir biçimde düzenleyerek yorumlamaktır (Yıldırım ve Şimşek, 2008: 227). Çalışmada tarama sonucu elde edilen makale ve tezlerin analiz edilmesinde ve yorumlanmasında adlandırma, kategori geliştirme, geçerlik ve güvenirliğin sağlanması, frekansların hesaplanması ve yorumlanması aşamalarına dikkat edilmiştir. Analizde adlandırma ve kategori geliştirme sürecinde makalelerin ve tezlerin her biri dikkatlice incelenmiş ve anahtar kelimeleri, konusu, yöntemi, örneklemi, veri toplama araçları, sonuçları ve önerileri gibi kategoriler altında sınıflandırılmışlardır. Geçerlik ve güvenirliğin sağlanmasında ele alınan makale ve tezlerin araştırmacılar arasında görüş birliğine dayalı olarak analiz edilmesine önem gösterilmiştir. Analiz edilen makale ve tezlerin belirlenen kategorilere dayalı bir şekilde tekrarlanma sıklıkları ve yüzdeleri hesaplanmış ve bu bilgilere dayalı yorumlar yapılmıştır. Araştırmacılar tarafından analizi yapılan makale ve tezler; yayın yılı, anahtar kelimeler, konu, örneklem, örneklemin seçildiği ülke, yöntem, veri toplama araçları, sonuçlar ve öneriler açısından analiz edilmiştir. Ancak bu süreçte bazı makalelerde araştırmanın yöntemi, veri toplama araçları ile ilgili açıklayıcı bilgilerin olmadığı görülmüştür. Bu durumda, araştırmacılar bu çalışmalara uygun yöntem ve veri analizi tekniğini kendileri adlandırmak yerine çalışmanın güvenirliği açısından herhangi bir müdahalede bulunmamayı tercih etmişlerdir. Tespit edilen bu tür durumlar tablolarda 'belirtilmemiş' şeklinde gösterilmiştir.

\section{Bulgular}

Bu çalışmanın alt problemlerine göre elde edilen bulgular yüzde ve frekans hesaplamaları yapılarak aşağıdaki gibi tablolaştırılmıştır.

Yurt dışında yaşayan Türk çocukları üzerine yapılan makalelerin yıllara göre dağılımı Tablo 3'te sunulmuştur.

Tablo 3.

Yurt dışında yaşayan Türk çocukları üzerine yapılan makalelerin yıllara göre dağılımı

\begin{tabular}{lcc}
\hline YIL & $f$ & $\%$ \\
\hline 2001 & 1 & 5.2 \\
2004 & 1 & 5.2 \\
2009 & 1 & 5.2 \\
2010 & 2 & 10.5 \\
2011 & 1 & 5.2 \\
2013 & 1 & 5.2 \\
2014 & 3 & 15.7 \\
2015 & 1 & 5.2 \\
2016 & 3 & 15.7 \\
2017 & 1 & 5.2 \\
2018 & 4 & 21 \\
\hline Toplam & 19 & 100 \\
\hline
\end{tabular}

Tablo 3 incelendiğinde yurt dışında yaşayan Türk çocukları üzerine 2000, 2002, 2003, 2005, 2006, 2007, 2008, 2012 yıllarında herhangi bir çalışmanın yapılmadığı görülmektedir. En fazla çalışma 
ise 2018 (\%21) yılında yapılmıştır. Buna göre, yurt dışında yaşayan Türk çocukları ile ilgili yapılan çalışmaların son yıllarda artış gösterdiği söylenebilir.

Yurt dışında yaşayan Türk çocukları üzerine yapılan lisansüstü tezlerin yıllara göre dağılımı Tablo 4'te gösterilmiştir.

Tablo 4.

Yurt dışında yaşayan Türk çocukları üzerine yapılan lisansüstü tezlerin yıllara göre dağılımı

\begin{tabular}{lcccccc}
\hline Yıl & \multicolumn{2}{c}{ Doktora } & \multicolumn{2}{c}{ Yüksek Lisans } & \multicolumn{2}{c}{ Toplam } \\
\hline & $f$ & $\%$ & $f$ & $\%$ & $f$ & $\%$ \\
\cline { 2 - 7 } 2005 & 1 & 11.1 & - & - & 1 & 5.5 \\
2007 & 1 & 11.1 & - & - & 1 & 5.5 \\
2010 & - & - & 1 & 11.1 & 1 & 5.5 \\
2011 & 2 & 22.2 & 1 & 11.1 & 3 & 16.6 \\
2013 & 1 & 11.1 & - & - & 1 & 5.5 \\
2014 & - & - & 1 & 11.1 & 1 & 5.5 \\
2015 & - & - & 3 & 33.3 & 3 & 16.6 \\
2016 & 2 & 22.2 & 1 & 11.1 & 3 & 16.6 \\
2017 & 1 & 11.1 & - & - & 1 & 5.5 \\
2018 & 1 & 11.1 & 2 & 22.2 & 3 & 16.6 \\
\hline Toplam & 9 & 100 & 9 & 100 & 18 & 100 \\
\hline
\end{tabular}

Tablo 4 incelendiğinde 2000,2001, 2002, 2003, 2004, 2006, 2008, 2009, 2012 yıllarında yurt dışında yaşayan Türk çocuklarına yönelik herhangi bir çalışmanın yapılmadığı görülmektedir. En fazla çalışmanın yapıldığı yıllar 2011, 2015, 2016 ve 2018 (\%16,6) yıllarıdır. Buna göre, yurt dışında yaşayan Türk çocukları ile ilgili yapılan tez çalışmalarının yıllara göre farklılık göstermekle birlikte 2011 yılından sonra arttığı görülmektedir.

Yurt dışında yaşayan Türk çocukları üzerine yapılan makalelerin anahtar kelime dağılımı Tablo 5 'te gösterilmiştir.

Tablo 5.

Yurt dışında yaşayan Türk çocukları üzerine yapılan makalelerin anahtar kelime dağılımı

\begin{tabular}{lcclcc}
\hline Anahtar Kelime & $f$ & $\%$ & Anahtar Kelime & $f$ & $\%$ \\
\hline İki Dillilik & 10 & 12 & İki Dilli Çocukların Gelişimi & 1 & 1.2 \\
Ana Dili & 6 & 7.2 & Göç Olgusu & 1 & 1.2 \\
Türkçe Öğretimi & 4 & 4.8 & Nesil Çatışması & 1 & 1.2 \\
Okul Öncesi Eğitim & 2 & 2.4 & Sosyalleşme & 1 & 1.2 \\
Türkçe Öğretmenleri & 2 & 2.4 & Kimlik & 1 & 1.2 \\
Batı Avrupa & 2 & 2.4 & Türkçe Dil Etkinlikleri & 1 & 1.2 \\
Hikâye Anlatma & 2 & 2.4 & Sözcük Seçimi & 1 & 1.2 \\
Ana Dil & 1 & 1.2 & Alman Eğitim Sistemi & 1 & 1.2 \\
Türkçe Öğrenme & 1 & 1.2 & Türk Göçmen Çocukları & 1 & 1.2 \\
Hikâye Öncesi Etkinlikler & 1 & 1.2 & Hikâye Sonrası Etkinlikler & 1 & 1.2 \\
Yurt Dışında Yaşayan Türk & 1 & 1.2 & Yurt Dışında Yaşayan Türk & 1 & 1.2 \\
Çocukları & & & Çocuklarının Dil Kazanımı & & \\
İviçre & 1 & 1.2 & Norveç & 1 & 1.2 \\
Dil Politikaları & 1 & 1.2 & Dil Bilgisi & 1 & 1.2 \\
Dil Edinimi & 1 & 1.2 & Ana Dili Ĕğitimi & 1 & 1.2 \\
Bulgaristan Cumhuriyeti & 1 & 1.2 & Hollanda & 1 & 1.2 \\
Öğrenci Memnuniyeti & 1 & 1.2 & Almanya'da Ana Dili Türkçe & 1 & 1.2 \\
Türkçe ve Türk Kültürü & 1 & 1.2 & Türkçenin Toplum Dilbilimsel & 1 & 1.2 \\
Ders Kitabı & & & Gücü & & \\
\hline
\end{tabular}




\begin{tabular}{llllll}
\hline Yazılı Anlatım & 1 & 1.2 & Okuma Olgunluğu & 1 & 1.2 \\
Çok Uluslu Aileler & 1 & 1.2 & Yabancı Dil & 1 & 1.2 \\
Yanlış Çözümleme Yöntemi & 1 & 1.2 & Almanya'daki Türk Çocukları & 1 & 1.2 \\
Iki Dilliliğin Ölçümü & 1 & 1.2 & Amerikalı Türkler & 1 & 1.2 \\
Öğretmen Görüşleri & 1 & 1.2 & Amerika'daki Türkler & 1 & 1.2 \\
Ders Kitabı İncelemesi & 1 & 1.2 & Amerika'da Türkçe & 1 & 1.2 \\
Söz Dizimi & 1 & 1.2 & Toplum Okulları & 1 & 1.2 \\
Sesletim & 1 & 1.2 & Türk Aile Yapısı & 1 & 1.2 \\
Konuşma Becerisi & 1 & 1.2 & Ana Dilin Devamlıı̆ı̆ı & 1 & 1.2 \\
Makedonya & 1 & 1.2 & Türk Cumhuriyeti & 1 & 1.2 \\
Baskın Dil & 1 & 1.2 & Fransa'da Türkçe Öğretimi & 1 & 1.2 \\
Iki Dilliliğin Sınıflandırılması & 1 & 1.2 & Bulgaristan'da Türkçe & 1 & 1.2 \\
& & & Öğretimi & & \\
Türkçe & 1 & 1.2 & Yurt Dışındaki Türkler & 1 & 1.2 \\
Kültür & 1 & 1.2 & Türkçe Öğretim Ortamları & 1 & 1.2 \\
\hline Toplam & & & & 83 & 100 \\
\hline
\end{tabular}

Tablo 5'te yurt dışında yaşayan Türk çocukları üzerine 2000-2018 yıllarında yapılmış olan makalelerin anahtar kelimeleri incelendiğinde toplamda 63 farklı anahtar kelimenin kullanıldığı görülmektedir. En sık kullanılan anahtar kelime "iki dillilik" (\%12) iken onu sırasıyla "ana dili" (\%7.2) ve "Türkçe öğretimi" (\%4.8) takip etmektedir. Tablo incelendiğinde bazı kavramlar için ortak bir kavram anlayışının olmadığı görülmektedir.

Yurt dışında yaşayan Türk çocukları üzerine yapılan lisansüstü tezlerin anahtar kelime dağılımı Tablo 6'da sunulmuştur.

Tablo 6.

Yurt dışında yaşayan Türk çocukları üzerine yapılan lisansüstü tezlerin anahtar kelime dağılımı

\begin{tabular}{lcclcc}
\hline Anahtar Kelime & $f$ & $\%$ & Anahtar Kelime & $f$ & $\%$ \\
\hline iki Dillilik & 8 & 11.1 & Kimlik & 1 & 1.3 \\
Ana Dili & 3 & 4.1 & Anadilsel Kayıp & 1 & 1.3 \\
Göç & 3 & 4.1 & Sesli Okuma & 1 & 1.3 \\
Türkçe ve Türk Kültürü Dersi & 3 & 4.1 & Iki Dilli & 1 & 1.3 \\
Anadil & 2 & 2.7 & Ana Dili Tutumu & 1 & 1.3 \\
Fransa & 2 & 2.7 & Yazma Becerisi & 1 & 1.3 \\
Belçika & 1 & 1.3 & Eşdizimsel Bilgi & 1 & 1.3 \\
3. Kuşak Türk Çocukları & 1 & 1.3 & Hikâye Sonrası Etkinlikler & 1 & 1.3 \\
Almanya & 1 & 1.3 & İviçre & 1 & 1.3 \\
Türkçe Eğitimi Yazılı Anlatım & 1 & 1.3 & Türkçe Dili Etkinlikleri & 1 & 1.3 \\
Frankfurt Modeli & 1 & 1.3 & Koala Projesi & 1 & 1.3 \\
Yabancılara Türkçe Öğretimi & 1 & 1.3 & Eğitsel Oyun & 1 & 1.3 \\
Kültür & 1 & 1.3 & Hikâye Anlatma & 1 & 1.3 \\
Zihin Dağarcı̆̆ı & 1 & 1.3 & Göç Etme Yaşı & 1 & 1.3 \\
İkamet Süresi & 1 & 1.3 & Ders Kitapları & 1 & 1.3 \\
Öğretmen & 1 & 1.3 & Kültür Aktarımı & 1 & 1.3 \\
Sesli Okuma Yöntem ve & 1 & 1.3 & Yurt Dışında Yaşayan Türk & 1 & 1.3 \\
Teknikleri & & & Çocuklarının Dil Kazanımı & & \\
Türkçe Eğitimi ve Öğretimi & 1 & 1.3 & Iki Dilli Türk Çocukları & 1 & 1.3 \\
Öz Düzenleyici Öğrenme & 1 & 1.3 & Yurt Dı̧̧ında Türkçe Öğretimi & 1 & 1.3 \\
Stratejileri & & & & & \\
Türkçe Öğretimi & 1 & 1.3 & Veli & 1 & 1.3 \\
İngiltere & 1 & 1.3 & Türkçe Eğitimi & 1 & 1.3 \\
\hline
\end{tabular}




\begin{tabular}{lcclcc}
\hline Metindilbilim & 1 & 1.3 & Ders Kitabı & 1 & 1.3 \\
Metinsellik & 1 & 1.3 & İsveç & 1 & 1.3 \\
Bulgaristan'da Türkçe Eğitimi & 1 & 1.3 & Görev Temelli Dil Öğretimi & 1 & 1.3 \\
Kelime Sıklığı & 1 & 1.3 & Okuduğunu Anlama & 1 & 1.3 \\
İki Dilli Eğitim & 1 & 1.3 & $\begin{array}{l}\text { Avrupa Diller İçin Ortak } \\
\text { Çerçeve Metni }\end{array}$ & 1 & 1.3 \\
$\begin{array}{l}\text { Modelleri } \\
\text { Iki Dilli Türk Öğrenciler }\end{array}$ & 1 & 1.3 & Hikâye Öncesi Etkinlikler & 1 & 1.3 \\
$\begin{array}{l}\text { Okul Öncesi Eğitim } \\
\text { Yurt Dışında Yaşan Türk }\end{array}$ & 1 & 1.3 & Ana Dil Öğretimi & 1 & 1.3 \\
Çocukları & 1 & 1.3 & & & \\
\hline Toplam & & & & 73 & 100 \\
\hline
\end{tabular}

Tablo 6'da yurt dışında yaşayan Türk çocukları üzerine 2000-2018 yıllarında yapılmış olan tezlerin anahtar kelimeleri incelendiğinde toplamda 57 farklı anahtar kelimenin kullanıldığı görülmektedir. En sık kullanılan anahtar kelime "iki dillilik" (\%11.1) iken onu sırasıyla "ana dili" (\%4.1), "göç" (\%4.1) ve "Türkçe ve Türk Kültürü dersi" (\%4.1) takip etmektedir.

Yurt dışında yaşayan Türk çocukları üzerine yapılan makalelerin konu dağılımı Tablo 7'de gösterilmiştir.

Tablo 7.

Yurt dışında yaşayan Türk çocukları üzerine yapılan makalelerin konu dağılımı

\begin{tabular}{llc}
\hline Konu & $f$ & $\%$ \\
\hline Dil Becerileri & 12 & 50 \\
Kültür ve Kültür Aktarımı & 5 & 20.8 \\
Dil Politikaları & 3 & 12.5 \\
Yöntem ve Teknikler & 2 & 8.3 \\
Kitap & 1 & 4.2 \\
Proje & 1 & 4.2 \\
\hline Toplam & 24 & 100 \\
\hline
\end{tabular}

Tablo 7’ye bakıldığında makalelerde en çok araştırılan konunun dil becerilerine (\%50) yönelik konular olduğu görülmektedir. İkinci sırada ise kültür ve kültür aktarımına yönelik olarak yapılmış olan çalışmalar yer almaktadır. Bu durum dilin yalnız bir beceri olarak ele alınmadığını ayrıca çocuğun toplumla ve o topluma ait kültürle sağlıklı bir ilişki kurmasını sağlayan unsur olarak kabul edildiğini göstermektedir. En az ele alınan konular ise yurt dışında yaşayan çocukların Türkçe ve Türk Kültürü dersi kapsamında kullandıkları kitaplar (\%4.1) ve iki dilli çocuklara yönelik olan projelerdir (\%4.1).

Yurt dışında yaşayan Türk çocukları üzerine yapılan lisansüstü tezlerin konu dağııımı Tablo 8 'de sunulmuştur.

Tablo 8.

Yurt dışında yaşayan Türk çocukları üzerine yapılan lisansüstü tezlerin konu dağı̆ımı

\begin{tabular}{lll}
\hline Konu & $f$ & $\%$ \\
\hline Dil Becerileri & 9 & 42.8 \\
Tutum & 3 & 14.2 \\
Kültür ve Kültür Aktarımı & 3 & 14.2 \\
Kitap & 2 & 9.5 \\
Yöntem-Teknik & 2 & 9.5 \\
Proje & 1 & 4.8 \\
Dil Politikaları & 1 & 4.8 \\
\hline Toplam & 21 & 100 \\
\hline
\end{tabular}


Tablo 8 incelendiğinde yurt dışında yaşayan Türk çocuklarına yönelik tezlerde en çok araştırılan konunun becerilere (\%42.8) yönelik olduğu görülmektedir. En az ele alınan konular proje (\%4.8) ve dil politikalarıdır (\%4.8).

Yurt dışında yaşayan Türk çocukları üzerine yapılan makalelerin örneklem dağılımı Tablo 9'da sunulmuştur.

Tablo 9.

Yurt dışında yaşayan Türk çocukları üzerine yapılan makalelerin örneklem dağılımı

\begin{tabular}{lll}
\hline Örneklem Türü & $f$ & $\%$ \\
\hline Öğrenci & 14 & 56 \\
Veli & 4 & 16 \\
Öğretmen & 4 & 16 \\
Proje - Program & 3 & 12 \\
\hline Toplam & 25 & 100 \\
\hline
\end{tabular}

Tablo 9 incelendiğinde yurt dışında yaşayan Türk çocukları üzerine yapılan bazı çalışmaların birden fazla örneklem üzerinde yapıldığı görülmektedir. Buna göre, çalışmalar en fazla öğrenci (\%56) üzerine yoğunlaşmaktadır, onu sırasıyla veli (\%16) ve öğretmen (\%16) izlemektedir. En az çalışmanın ise projelere (\%12) yönelik olduğu görülmektedir. Öğrenci merkezli çalışmaların sıklığı hedef kitlenin odağa alındığını göstermektedir.

Yurt dışında yaşayan Türk çocukları üzerine yapılan lisansüstü tezlerin örneklem dağılımı Tablo 10'da gösterilmiştir.

Tablo 10.

Yurt dışında yaşayan Türk çocukları üzerine yapılan lisansüstü tezlerin örneklem dağı̆ımı

\begin{tabular}{lll}
\hline Örneklem Türü & $f$ & $\%$ \\
\hline Öğrenci & 15 & 68.2 \\
Veli & 3 & 13.6 \\
Kitap & 2 & 9 \\
Öğretmen & 1 & 4.5 \\
Proje - Program & 1 & 4.5 \\
\hline Toplam & 22 & 100 \\
\hline
\end{tabular}

Tablo 10 incelendiğinde bazı tez çalışmalarının birden fazla örneklem üzerinde yapıldığı görülmektedir. Buna göre, çalışmalar en fazla öğrenci (\%68.2) üzerinde yoğunlaşmaktadır, onu sırasıyla veli (\%13.6) ve kitap (\%9) izlemektedir. En az çalışma ise öğretmenler (\%4.5) ve projeprogramlarla (\%4.5) ilgili yapılmıştır.

Yurt dışında yaşayan Türk çocukları üzerine yapılan makalelerin örnekleminin seçildiği ülkelere göre dağılımı Tablo 11'de gösterilmiştir.

Tablo 11.

Yurt dışında yaşayan Türk çocukları üzerine yapılan makalelerin örnekleminin seçildiği ülkelere göre dăğılımı

\begin{tabular}{lll}
\hline Ülke & $f$ & $\%$ \\
\hline Almanya & 5 & 26.3 \\
Fransa & 3 & 15.7 \\
Amerika & 1 & 5.2 \\
Belçika & 1 & 5.2 \\
Avustralya & 1 & 5.2 \\
İngiltere & 1 & 5.2 \\
Makedonya & 1 & 5.2 \\
\hline
\end{tabular}




\begin{tabular}{lll}
\hline Norveç & 1 & 5.2 \\
İsviçre & 1 & 5.2 \\
Hollanda & 1 & 5.2 \\
Danimarka & 1 & 5.2 \\
Bulgaristan & 1 & 5.2 \\
Belirtilmemiş & 1 & 5.2 \\
\hline Toplam & 19 & 100 \\
\hline
\end{tabular}

Tablo 11'de görüldüğü üzere yurt dışında yaşayan Türk çocukları ile ilgili akademik çalışmalar en fazla Almanya'da (\%26.3) yapılmış iken onu ikinci sırada Fransa (\%15.7) takip etmektedir. Çalışmalardan biri farklı ülkelerde görev yapan öğretmenlerle yürütüldüğü için "belirtilmemiş" seçeneği içerisinde gösterilmiştir.

Yurt dışında yaşayan Türk çocukları üzerine yapılan lisansüstü tezlerin örnekleminin seçildiği ülkelere göre dağılımı Tablo 12'de sunulmuştur.

Tablo 12.

Yurt dışında yaşayan Türk çocukları üzerine yapılan lisansüstü tezlerin örnekleminin seçildiği ülkelere göre dağılımı

\begin{tabular}{lll}
\hline Ülke & $f$ & $\%$ \\
\hline Almanya & 4 & 22.2 \\
Fransa & 4 & 22.2 \\
İsviçre & 2 & 11.1 \\
Amerika & 1 & 5.5 \\
İngiltere & 1 & 5.5 \\
Romanya & 1 & 5.5 \\
İsveç & 1 & 5.5 \\
Yunanistan & 1 & 5.5 \\
Belçika & 1 & 5.5 \\
Bulgaristan & 1 & 5.5 \\
Belirtilmemiş & 1 & 5.5 \\
\hline Toplam & 18 & 100 \\
\hline
\end{tabular}

Tablo 12 incelendiğinde lisansüstü tezlerin örneklemlerinin en fazla \%22.2 ile Almanya ve Fransa, \%11.1 ile de İsviçre'den seçildiği görülmektedir. Çalışmaların bu iki ülkede daha çok yapılması bu ülkelerdeki Türk nüfusunun fazla olmasıyla açıklanabilir. Çalışmalardan biri yurt dışında yaşayan Türk çocuklarına Türkçe öğretimiyle ilgili kitaplar üzerine yapıldığı için herhangi bir ülke bilgisine rastlanmamıştır. Bu nedenle tabloda bu çalışmanın yapıldığı ülke "belirtilmemiş" şeklinde gösterilmiştir.

Yurt dışında yaşayan Türk çocukları üzerine yapılan makalelerin yöntem dağılımı Tablo $13^{\prime}$ te gösterilmiştir.

Tablo 13.

Yurt dışında yaşayan Türk çocukları üzerine yapılan makalelerin yöntem dağılımı

\begin{tabular}{|c|c|c|c|}
\hline $\begin{array}{l}\text { Yöntem } \\
\text { Nitel }\end{array}$ & & $f$ & $\%$ \\
\hline & & 8 & 42.1 \\
\hline & - Belirtilmemiş & 4 & 21 \\
\hline & - Durum Çalışması & 2 & 10.5 \\
\hline & - Alan Araştırması & 1 & 5.2 \\
\hline & - Betimsel Yöntem & 1 & 5.2 \\
\hline
\end{tabular}




\begin{tabular}{|c|c|c|c|}
\hline \multirow{6}{*}{ Nicel } & & 7 & 36.8 \\
\hline & - Betimsel Tarama & 2 & 10.5 \\
\hline & - Tekil Tarama & 2 & 10.5 \\
\hline & - $\quad$ ilişkisel Tarama & 1 & 5.2 \\
\hline & - Tarama & 1 & 5.2 \\
\hline & - Belirtilmemiş & 1 & 5.2 \\
\hline Karma & & 1 & 5.2 \\
\hline Belirtilmemiş & & 3 & 15.7 \\
\hline Toplam & & 19 & 100 \\
\hline
\end{tabular}

Tablo 13'te yurt dışında yaşayan Türk çocukları üzerine 2000-2018 yıllarında yapılmış olan makaleler kullanılan yöntemler açısından incelendiğinde çalışmalarda nitel yöntemin ön plana çıktığı (\%42.1) görülürken nicel (\% 36.8) ve karma (\% 5.2) modellerin daha az kullanıldığı sonucuna varılmıştır. Çalışmaların üçünde ise herhangi bir yöntem belirtilmemiştir.

Yurt dışında yaşayan Türk çocukları üzerine yapılan lisansüstü tezlerin yöntem dağılımı Tablo $14^{\prime}$ te sunulmuştur.

Tablo 14.

Yurt dışında yaşayan Türk çocukları üzerine yapılan lisansüstü tezlerin yöntem dağııımı

\begin{tabular}{lllcc}
\hline Yöntem & & $f$ & $\%$ \\
\hline Nitel & & 7 & 38.8 \\
\cline { 2 - 5 } & $\bullet$ & Betimsel Tarama & 3 & 16.6 \\
& $\bullet$ & Doküman Incelemesi & 2 & 11.1 \\
& $\bullet$ & Alan Araştırması & 1 & 5.5 \\
& $\bullet$ & Olgubilim & 1 & 5.5 \\
\hline Nicel & & 6 & 33.3 \\
\cline { 2 - 5 } & $\bullet$ & Tarama Araştırması & 4 & 22.2 \\
& $\bullet$ & Deneysel & 1 & 5.5 \\
& $\bullet$ & Diğer & 1 & 5.5 \\
\hline Karma & & 3 & 16.6 \\
\hline Belirtilmemiş & & 2 & 11.1 \\
\hline Toplam & & 18 & 100 \\
\hline
\end{tabular}

Tablo 14'te yurt dışında yaşayan Türk çocukları üzerine 2000-2018 yıllarında yapılmış olan tezler yöntem açısından incelendiğinde çalışmalarda nitel yöntemin ön plana çıktığı (\%38.8) görülürken nicel (\%33.3) ve karma (\%16.6) modellerin daha az kullanıldığı görülmektedir. Çalışmalardan ikisinde herhangi bir yöntem bölümü veya bilgisi verilmemiştir.

Yurt dışında yaşayan Türk çocukları üzerine yapılan makalelerde kullanılan veri toplama araçlarının dağılımı Tablo 15'te sunulmuştur.

Tablo 15.

Yurt dışında yaşayan Türk çocukları üzerine yapılan makalelerde kullanılan veri toplama araçları dağılımı

\begin{tabular}{|c|c|c|}
\hline Veri Toplama Araçları & $f$ & $\%$ \\
\hline Anket/Ölçek & 17 & 56.5 \\
\hline Öğrenci & 12 & 40 \\
\hline Öğretmen & 3 & 10 \\
\hline Veli & 2 & 6.6 \\
\hline Ölçek & 5 & 16.6 \\
\hline Öğrenci & 5 & 16.6 \\
\hline
\end{tabular}




\begin{tabular}{lccc}
\hline Kişisel Bilgi Formu & 5 & 16.6 \\
& Öğrenci & 3 & 10 \\
& Veli & 2 & 6.6 \\
\hline \multicolumn{2}{c}{ Görüşme Formu } & 4 & 13.3 \\
& Öğrenci & 2 & 6.7 \\
& Öğretmen & 1 & 3.3 \\
& Veli & 1 & 3.3 \\
\hline Gözlem & & 3 & 10 \\
& Öğrenci & 3 & 10 \\
\hline Doküman & & 1 & 3.3 \\
& Öğrenci & 1 & 3.3 \\
\hline Diğer & & 1 & 3.3 \\
\hline Toplam & & 30 & 100 \\
\hline
\end{tabular}

Tablo 15 incelendiğinde yurt dışında yaşayan Türk çocuklarına yönelik yapılan makalelerde en fazla başvurulan veri toplama aracının anket/ölçek (\%56.6) olduğu görülmektedir. Anket/ölçeğin en fazla uygulandığı örneklem grubunu ise öğrenciler (\%20) oluşturmaktadır. En az başvurulan veri toplama aracı ise öğrencilerden elde edilen dokümanlardır (\%3.3). Bazı çalışmalarda birden fazla veri toplama aracı kullanılmıştır. Bir çalışmada ise mevcut politikaların durum değerlendirmesi yapıldığı için herhangi bir veri toplama aracı kullanılmamıştır.

Yurt dışında yaşayan Türk çocukları üzerine yapılan lisansüstü tezlerde kullanılan veri toplama araçlarının dağııımı Tablo 16 'da gösterilmiştir.

Tablo 16.

Yurt dışında yaşayan Türk çocukları üzerine yapılan lisansüstü tezlerde kullanılan veri toplama araçları dağılımı

\begin{tabular}{lcll}
\hline Veri Toplama Araçları & $f$ & $\%$ \\
\hline Anket/Ölçek & Öğrenci & 22 & 47.8 \\
& Veli & 18 & 39.1 \\
& Ögrretmen & 2 & 4.3 \\
& Program & 1 & 2.2 \\
& & 1 & 2.2 \\
\hline Doküman & Öğrenci & 7 & 15.2 \\
& Öğretmen & 5 & 10.8 \\
& Kitap-program & 1 & 2.2 \\
& & 1 & 2.2 \\
\hline Kişisel Bilgi Formu & Öğrenci & 7 & 15.2 \\
& Veli & 3 & 6.5 \\
& Öğretmen & 3 & 6.5 \\
& Öğrenci & 1 & 2.2 \\
\hline Gözlem & Öğretmen & 6 & 13 \\
& Veli & 4 & 8.6 \\
& & 1 & 2.2 \\
& Öğrenci & 1 & 2.2 \\
\hline Görüşme Formu & Ögretmen & 4 & 8.6 \\
& Veli & 2 & 4.3 \\
& & 1 & 2.2 \\
\hline Toplam & 1 & 2.2 \\
\hline
\end{tabular}


Tablo 16 incelendiğinde yurt dışında yaşayan Türk çocuklarına yönelik yapılan tezlerde en fazla başvurulan veri toplama aracının anket/ölçeğin (\%47.8) olduğu görülmektedir. Anket/ölçeklerin en fazla uygulandığı örneklem grubunu öğrenciler (\%39.1) oluşturmaktadır. Başarı testleri, tutum ölçekleri, yetenek testleri, algı ölçekleri, anketler gibi araçlar tek bir başlık altında "anket/ölçek" olarak toplanmıştır. En az kullanılan veri toplama aracı ise görüşme formlarıdır (\%8.6). Bazı çalışmalarda birden fazla veri toplama aracı kullanılmıştır.

Yurt dışında yaşayan Türk çocukları üzerine yapılan makalelerin sonuç dağılımı Tablo 17 'de gösterilmiştir.

Tablo 17.

Yurt dışında yaşayan Türk çocukları üzerine yapılan makalelerin sonuç dağılımı

\begin{tabular}{lcc}
\hline Sonuçlar & $f$ & $\%$ \\
\hline Çocuklarla ilgili sonuçlar & 4 & 51.2 \\
& 4 & \\
\hline
\end{tabular}

- İki dilli öğrencilerin en fazla yanlış yaptığı alanın dil bilgisi olduğu; bunu sırasıyla sözcük seçimi, söz dizimi ve sesletim yanlışlarının takip ettiği,

- Öğrencilerin Türkçe dersi ve ders kitabına karşı olumlu tutuma sahip olduğu,

$6 \quad 13.6$

- Öğrencilerin Türkçeyi, aileleriyle ve Türk arkadaşlarıyla iyi iletişim kurmak, Türkçeyi etkili bir biçimde kullanmak, derslerde başarılı olmak gibi nedenlerle öğrenmeyi amaçladıkları,

- Çocuklar akranlarıyla olan iletişimlerinde ikinci dili göreceli olarak kullanmalarına karşın, genellikle Türkçeyi tercih ettikleri,

- Türk çocuklarının yaşadıkları toplumda neler olup bittiğini anlamaları ve kendi düşüncelerini ifade etmek için ikinci dili; geldikleri toplumun ve ait oldukları kökenin deneyimlerini, duygularını, ilişkilerini ve değerlerini anlayabilmek ve aktarabilmek için de ana dilleriini öğrenmek zoruna oldukları,

- Okullarda ana dili kulüplerinin açılması, yaz kamplarının düzenlenmesi, çocukların akran grupları ile birlikte olması, düzenlenecek kültür festivalleriyle çocukların dilkültür bağlantısı kurması çocukların dili yaşayarak öğrenmesini sağladığı,

- İki dilli öğrencilerin yaptığı yanlışlar cinsiyete göre incelendiğinde erkek çocuklarının kız çocuklarından daha fazla yanlış yaptığı, dil yeterliliği bakımından kızların daha iyi olduğu,

- Öğrencilerin daha çok Türkçe kitapları ve TV programlarını tercih ettiği,

- İki dilli Türk öğrencilerin konuşmaya başlama konusunda genellikle ortalama bir seviyede oldukları fakat konuşmayı uygun bir sonuçla tamamlama konusunda sıkıntı yaşadıkları ve sonuç bölümüne gelmeden konuşmayı bitirdikleri,

- İki dilli Türk öğrencilerin şiveli konuşmalara sahip oldukları ve bu durumun onların sözcük dağarcığı gelişimine olumsuz etki ettiği,

- İki dilli öğrencilerin noktalama işaretlerini yanlış kullandığı, noktalama işaretleriyle ilgili yapılan yanlışlarda da nokta, kesme işareti ve virgül en çok hata yapılan noktalama işaretleri olduğu,

- İki dilli öğrencilerin yazım yanlışları açısından ele alınan sonuçlarına bakıldığında bağlaç olan da, de'nin yazılışı, ayrı/bitişik yazılan kelimeler, büyük harflerin kullanımı ile ilgili yanlışların öne çıktığı,

- Öğrencilerin, Türkçe öğrenmede karşılaştıkları sorunlara ilişkin en çok yazma ve konuşma gibi ifade becerilerinde sorun yaşadığı,

- Dil gelişimi ile okuma olgunluğu arasında da pozitif yönlü bir ilişki olduğu,

- İki dilli Türk öğrencilerin konuşma becerilerinin okul öncesi eğitim alma durumuna göre anlamlı bir farklılı̆̆a sahip olduğu,

- îkinci dili Türkçe olan öğrencilerin konuşma becerilerinin diğerlerine göre daha düşük düzeyde olduğu, 
- Yurt dışında Türkçe dersine giren Türk öğrencilerinin, öğrenim gördükleri derse ilişkin genelde bir memnuniyetsizlik içinde oldukları,

- İki dilli çocuklar üzerine yapılan zekâ testlerinin sonuçlarının, bu çocukların tek dilli çocuklara göre daha zeki ve daha çeşitli zekâ yapılarına sahip olduğunu gösterdiği,

- Öğrencilerin evde ve arkadaşları arasında iki dili de karışık olarak kullandıkları,

- Öğrencinin yakın arkadaşları içinde bir tane çok iyi Türkçe konuşan kişi bulunduğu,

- Öğrencilerin gelecekteki çocuklarının Türkçe öğrenmesini istedikleri,

- İki kültür arasında kalan Türk çocuklarının üzerindeki baskıların, toplumsal beklentiler sebebiyle arttığı,

Ailelerle ilgili sonuçlar

- Ailelerin demografik özelliklerinin, dil tercihlerinin ve dil öğretimine karşı 1 tutundukları tavrın çocukların dil becerilerini etkilediği,

- Ailelerin çok kültürlülük, iki dillilik, iki dilliğin çocuğa sağlayacağı zihinsel kazanımlar ve faydalar konusunda bilinçlenmesi gerektiği,

- Türk kökenli göçmen ailelerin Türkçeyi tam ve doğru olarak kullanamamaları, ayrıca ikinci dili de tam olarak bilmemeleri çocukların her iki dili edinebilmeleri için gerekli olan sosyal bağlamı oluşturamamalarına neden olduğu ve bu durumun çocukların her iki dilde de yarım dillilik (semilingual) olgusuyla karşı karşıya kalmasına ve her iki dili de yarım olarak edinmesine neden olduğu,

- Ailelerin çocuklarının iki dili ya da baskın dili bilmelerinin onları avantajlı konuma getireceğini düşündükleri,

- Ailelerin yurt dışında bazı ülkelerde düzenlenen çok kültürlülük politikasından memnun olmadığı,

Türkçe öğretimiyle ilgili sonuçlar

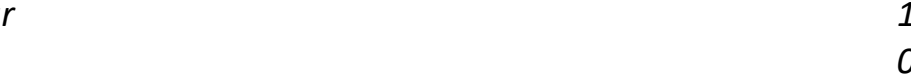

- Türkçe öğretiminde program, yöntem ve tekniklerde sıkıntılar olduğu; kaynakların, $\begin{array}{llll}\text { ders süresinin ve içeriklerin yetersiz olduğu ve sistemli olarak Türkçe öğretimi } & 7 & 70\end{array}$ yapılmadığı,

- Türk okullarının iki dilli çocuklara Türkçe öğretimini desteklediği, $\quad 1 \quad 10$

- Türkçenin miras ve sosyal dil olarak öğretildiği, $\quad 1 \quad 10$

- Türkçe öğretimindeki zorluklar ve kolaylıkların Türklerin aidiyet duygusunu ve kimliklerini şekillendirdiği,

- Göçmenlerin yaşadıkları topluma uyum sağlayabilmek için baskın dili öğrendiği ve bu durumun ana dili kaybıyla sonuçlandığı,

$9 \quad 10.5$

- Ana dilini iyi bilmenin ikinci dil edinimini de olumlu yönde etkilediği,

- Ana dilini canlı tutmanın yaşadığı toplumun dilini öğrenmeyi engellemediği,

- Yurtdışındaki Türkçe kullanımının, Türkçe dil girdisinin, eğitimsel ve çevresel faktörlerin iki dilliliğin hedeflediği ikili okur-yazarlık becerilerini kazandırmakta yetersiz olduğu,

- Türkçenin genellikle ailede öğretildiği,

- Öğrencilerin, velilerin ve öğretmenlerin birbirine paralel olarak ana dili Türkçenin öğrenilmesine yönelik amaçlarının benzer olduğu,

- Almanya'da Türk medyasının büyüyen etkisinin kararsız kimliklere sebep olduğu, Eğitim politikalarıla ilgili sonuçlar

- Batı Avrupa'da göçmen gruplara yönelik uygulanan eğitim politikalarının Avrupa Birliği'nin "azınlık politikalarına" ilişkin söylemleri ile taban tabana zıt olduğu ve bu durumun Batı Avrupa'da yetişen 2 milyon civarındaki Türk gençliğinin ana dili 
gelişimini çok olumsuz etkilediği,

\begin{tabular}{lll}
\hline Toplam & 8 & 100 \\
& 6 & \\
\hline
\end{tabular}

Tablo 17 'de yurt dışında yaşayan Türk çocukları üzerine yapılmış olan makalelerin benzer sonuçları birer başlık altında toplanarak sunulmuştur. Bu şekliyle çalışmaların sonuçları toplam 6 ana başlıkta ele alınmıştır. Bu doğrultuda Tablo $17^{\prime}$ de çalışmalardan elde edilen sonuçların en çok çocuklarla/öğrencilerle ilgili (\%51.2) olduğu görülmektedir. Daha sonra sırayla ailelerle ilgili (\%24.4), Türkçe öğretimi ile ilgili (\%11.6), ana dili ile ilgili (\%10.5), medya ile ilgili (\%1.7) ve eğitim politikaları ile ilgili (\%1.7) sonuçların elde edildiği görülmektedir. Çalışmalardan en fazla elde edilen sonuçların; ailelerin demografik özelliklerinin, dil tercihlerinin ve dil öğretimine karşı tavırlarının çocukların dil becerilerini etkilediği (\%52.4), yurt dışında yaşayan Türk çocuklarına Türkçe öğretiminde kullanılan program, yöntem, teknik ve materyallerin yetersiz olduğu (\%70), iki dilli öğrencilerin en fazla yanlış yaptığı alanın dil bilgisi olduğu; bunu sırasıyla sözcük seçimi, söz dizimi ve sesletim yanlışlarının takip ettiği (\%13.6), öğrencilerin Türkçe dersine ve ders kitaplarına yönelik olumlu tutuma sahip olduğu (\%11.7)görülmektedir.

Yurt dışında yaşayan Türk çocukları üzerine yapılan lisansüstü tezlerin sonuç dağııımı Tablo $18^{\prime}$ de gösterilmiştir.

Tablo 18.

Yurt dışında yaşayan Türk çocukları üzerine yapılan lisansüstü tezlerin sonuç dağılımı

\begin{tabular}{lcc} 
Sonuçlar & $f$ & $\%$ \\
Çocuklarla ilgili Sonuçlar & 50 & 60.2 \\
\hline
\end{tabular}

- Öğrencilerin öz düzenleyici öğrenme stratejilerini kullanmalarının dil becerilerini geliştirdiği,

- Öz düzenleyici öğrenme stratejilerini kullanmanın öğrencilerin motivasyonunu, özgüvenini ve dersin ilgi çekiciliğini artırarak dersi kalııı hale getirdiği,

- Bireylerin akademik başarıları üzerinde ailelerin demografik özelliklerinin etkisi olduğu,

- İki dilli azınlık ilkokullarından mezun olup ortaokula devam eden iki dilli

öğrencilerin ana dili ve ikinci dilde okuduğunu anlama, yazma, dinleme ve $\begin{array}{lllll}4 & 8\end{array}$ konuşma becerilerinde beklenenin altında kaldığı,

- İki dilli bireyler yazılı ve sözlü anlatım becerileri ile sözcük dağarcığı bakımından geri planda kaldığı,

- Bireylerin aileleriyle ve çevresiyle iletişim kurmada tercih ettikleri dilin öğrencilerin dil becerileri üzerinde etkili olduğu,

- Öz düzenleyici öğrenme stratejilerini kullanmanın öğrencilerin günlük yaşamına da katkı sağladığı,

- Öğrencilerin günlük yaşamına uyarladığı (mektup yazma, bir arkadaşına hediye vermek, süreli yayın takip etme vb.) etkinliklerin dil becerilerini daha kalıcı hale getirdiği,

- Çok kültürlü sınıflarda aynı kültürden olan öğrencilerin dil becerilerinin gelişiminde olumsuzlukların olduğu,

- Öğrencilerin Türkçe ve Türk kültürü derslerine ilgi duymadığı ve ailelerin zoruyla derslere geldiği,

- Türkçe kitap okuma ve ulaşma sıklığının yüksek olduğu bireylerde okuma alışkanlığının yüksek olduğu ve dil becerilerini kullanmada daha aktif olduğu,

- Çocukların Türkçe öğrenmeye karşı olumlu tutumları olduğu,

- Öğrencilerin Türkçe kelime hazinesinin yetersiz olduğu,

- Öğrencilerin çoğunun evinde iki dil kullanıldığı,

- Evde iki dillilik çok, tek dillilik az olduğu için öğrencinin Türkçe ile olan bağının
$5 \quad 10$

48

48

48

48

36

36

24

24

24

24

24

24

12 
zayıfladığı,

- Öğrencilerin, Türkçe dersine aile ve çevre faktörü yüzünden katıldığı, $\quad \begin{array}{lll}1 & 2\end{array}$

- Göçmen çocuklarının çoğunun kendini Türk olarak tanımlamadığı,

- Yurt dışında yaşayan Türk çocuklarında konuşma dilinin ikinci dili ve ağız özelliği etkisi ile standart Türkçeden uzaklaştığı,

- Dil kazanımında kardeş sayısının etkili olmadığı,

- Ailelerin gittikleri ülkelerde kalma sürelerinin çocukların dil kazanımlarında önemli bir farklılığa yol açmadığı,

- Öğrencilerin Türkçe konuşulan ortamda daha rahat hissettiği,

- Türkçe öğrenmenin kültürel ve kimliksel gelişime yardımcı olduğu,

- Ana dilinin ikinci dili destekleyici ve geliştirici olduğu kanısına dayanan dilsel hipotez kuramına varıldığı,

- Türkçenin sadece ev ortamında kullanıldığı,

12

- Ana dilini öğrenmenin ikinci dil öğrenmeye yardımcı olduğu,

$13 \quad 15.7$

- Cinsiyetin Türkçeye (ana dilini) yönelik tutumlar üzerinde etkili olmadığı,

23.1

- Ana dilini öğrenmenin ikinci dil öğrenmeye katkı sağlamadığı,

- Ana diline maruz kalmanın önemli olduğu,

- Ana dili kullanımında birinci kuşak göçmenlerin ikinci kuşaklardan daha iyi durumda olduğu,

- Dil öğretimi için düzenlenen etkinliklerin bireye görelik, seviyesine uygunluk ve ilgi çekicilik gibi ilkelere uygun hazırlandığında öğretimin etkililiğinin arttı̆̆ı,

- Türkçe ve Türk kültürü dersi içeriği ile programı arasında uyumsuzluklar olduğu,

- Türkçe ve Türk Kültürü ders kitaplarının bağdaşıklık ve tutarlılığa uygun olduğu,

- Türkçe ve Türk Kültürü ders kitaplarındaki metinlerin kısa ve eğitici olmadığı,

- Türkçe ve Türk Kültürü ders kitaplarındaki görsellerin düzeye uygun olduğu,

- Türkçe ve Türk Kültürü ders kitaplarındaki kültürel ögelerin sınıf düzeyine göre dengeli biçimde artmadığı,

- Türkçe ve Türk Kültürü ders kitaplarındaki bazı ögelerin sınıf düzeyine uygun olmadığı,

- Derse haftalık katılım süresi 2 gün olanların Türkçe dersi tutumlarının katılım süresi 1 gün olan öğrencilere göre daha yüksek olduğu,

\begin{tabular}{|c|c|c|}
\hline Ailelerle ilgili Sonuçlar & 3 & 3.6 \\
\hline $\begin{array}{l}\text { - Türk kültürü ve diğer kültürler ile ilgili ön yargıları ortadan kaldırmak için ailelerin } \\
\text { gerekli hizmet içi eğitim ve seminerlere katılım göstermelerinin gerektiği, }\end{array}$ & 1 & 33.3 \\
\hline $\begin{array}{l}\text { - Anne babadan yeterince destek alamamanın öğrencilerin dil başarılarını olumsuz } \\
\text { etkilediği, }\end{array}$ & 1 & 33.3 \\
\hline $\begin{array}{l}\text { - Ailelerin çocuklarının iki dili de bilmelerinin onları avantajlı konuma getireceğini } \\
\text { düşündükleri, }\end{array}$ & 1 & 33.3 \\
\hline Projelerle Illgili Sonuçlar & 3 & 3.6 \\
\hline $\begin{array}{l}\text { - KOALA projesinin ailenin bireye yönelik ilgi eksikliğinin dezavantajlarını gidermede } \\
\text { etkili olduğu, }\end{array}$ & 1 & 33.3 \\
\hline $\begin{array}{l}\text { - Türkçe öğretmenlerinin KOALA ile öğrencilerin eğitimsel başarılar elde etmelerinde } \\
\text { destek sağlandığını belirttikleri, }\end{array}$ & 1 & 33.3 \\
\hline $\begin{array}{l}\text { - KOALA'nın kültürler arası iletişim ve öğrenmede önemli bir etken olarak } \\
\text { görüldüğü, }\end{array}$ & 1 & 33.3 \\
\hline Öğretmenlerle ilgili sonuçlar & 2 & 2.4 \\
\hline
\end{tabular}
öğretmenlere gerekli hizmet içi eğitim ve seminerler verilmediği, 
- Öğretmenlerin ve okul müdürlerinin iki dilli olmamasının eğitimsel ve kişisel $\begin{array}{lll}1 & 50\end{array}$ problemlere neden olduğu,

\begin{tabular}{lcc}
\hline Çok Kültürlülükle Illgili Sonuçlar & 1 & 1.2 \\
\hline $\begin{array}{l}\text { Anne babadan yeterince destek alamamanın öğrencilerin dil başarılarını olumsuz } \\
\text { etkilediği, }\end{array}$ & 1 & 100 \\
\hline Toplam & 83 & 100 \\
\hline
\end{tabular}

Tablo 18 'de yurt dışında yaşayan Türk çocukları üzerine yapılmış olan lisansüstü tezlerinin benzer sonuçları bir madde altında birleştirilerek sunulmuştur. Bu birleştirme sonucunda yaklaşık 45 farklı sonucun elde edildiği görülmektedir. Bu sonuçlar 7 ana başlık altında ele alınmıştır. Tablo 18 incelendiğinde araştırmalarda en çok çocuklarla ilgili sonuçların (\%60.2) elde edildiği görülmektedir. Daha sonra sırayla ana diliyle (\%15.7), Türkçe öğretimiyle (\%13.3), ailelerle (\%3.6), projelerle (\%3.6), öğretmenlerle (\%2.4) ve çok kültürlülükle (\%1.2) ilgili sonuçların tespit edildiği belirlenmiştir. Tablo 18 'de en fazla öğrencilerin öz düzenleyici öğrenme stratejilerini kullanmalarııın dil becerilerini geliştirdiği (\%10), öz düzenleyici öğrenme stratejilerini kullanmak öğrencilerin motivasyonunu, özgüvenini ve dersin ilgi çekiciliğini artırarak dersi kalııı hale getirdiği (\%8), ailelerin demografik özellikleri bireylerin akademik başarısında etkili olduğu (\%8), iki dilli azınlık ilkokullarından mezun olup ortaokula devam eden iki dilli öğrencilerin ana dili ve ikinci dilde okuduğunu anlama, yazma, dinleme ve konuşma becerilerinde beklenenin altında kaldığı (\%8), iki dilli bireylerin yazılı ve sözlü anlatım becerileri ve sözcük dağarcığı bakımından geri kaldığı (\%8) ve bireylerin aileleriyle ve çevresiyle iletişim kurmada tercih ettikleri dilin öğrencilerin dil becerileri üzerinde etkili olduğu (\%8) sonuçlarının elde edildiği görülmektedir.

Yurt dışında yaşayan Türk çocukları üzerine yapılan makalelerin öneri dağııımı Tablo 19'da gösterilmiştir.

Tablo 19.

Yurt dışında yaşayan Türk çocukları üzerine yapılan makalelerin öneri dağılımı

\begin{tabular}{lcc}
\hline Öneriler & $f$ & $\%$ \\
\hline Hükümetlere Yönelik Öneriler & 30 & 35.2 \\
\hline - Türkçe eğitimini sağlamak için gerekli mercilerle iş birliği yapmalı, & 6 & 20 \\
- İki dilli eğitim modelleri/programları geliştirilmeli ve desteklenmeli, & 5 & 16.6 \\
- Nitelikli ve iki dilli materyaller geliştirmeli, & 4 & 13.3 \\
- Genel dil eğitimini desteklemeli, & 4 & 13.3 \\
- Türkçe ve Türk Kültürü dersinin haftalık süresi uzatılmalı ve zorunlu ders & 2 & 6.6 \\
- hâline getirilmeli, & 2 & 6.6 \\
- Nil-kültür ilişkisini destekleyici kültürel etkinlikler düzenlemeli, & 2 & 6.6 \\
- Öğretmenlikletmenler yetiştirilmeli, & 2 & 6.6 \\
- Türk diline karşı olumsuz tutumlar giderilmeli, & 1 & 3.3 \\
- Yapılan çalışmalardan hareketle eğitim politikalarına yön vermeli, & 1 & 3.3 \\
- Öğretim programları dil ve kültürü kazandırmada etkin hâle getirilmeli, & 1 & 3.3 \\
\hline Aileye Yönelik Öneriler & 17 & 20 \\
\hline - Aileler Türkçe öğrenimi konusunda bilinçlendirilmeli, & 10 & 58.8 \\
- Aileler çocuklarının dil gelişimini destekleyici faaliyetlerde bulunmalı, & 6 & 35.3 \\
- Çocukların Türkçeye maruz kalacakları ortamlar oluşturmalı, & 1 & 5.9 \\
\hline Öğretmene Yönelik Öneriler & 16 & 18.8 \\
\hline - Türkçenin kullanılacağı ortamlar düzenlemeli, & 7 & 43.8 \\
- Türkçe öğretimini destekleyici materyal kullanmalı, & 4 & 25 \\
- Ana dili, ikinci dil ediniminde yardımcı olarak kullanılmalı, & 3 & 18.8 \\
- Ana dilindeki kavramsal yetersizlikler belirlenmeli, & 1 & 6.3
\end{tabular}


- Dil değerlendirme araçları geliştirilmeli, Kitaba Yönelik Öneriler

$1 \quad 6.3$

- Türkçe ve Türk Kültürü dersinin içeriği öğrenciye ve yaşadığı ülkeye göre düzenlenmeli,

- Türkçe ve Türk Kültürü dersinde kullanılan kitapların niteliği iyileştirilmeli,

$15 \quad 17.6$

- Okullarda ders kitabının yanı sıra Türkçe okuma kitaplarına yer verilmeli,

83.3

- Günlük hayatla ilişkilendirilmeli,

320

- Görseller ilgi çekici olmalı,

Yönteme Yönelik Öneriler

$1 \quad 6.7$

- Dil becerilerine yönelik etkinlikler (web tabanlı, bilgisayar oyunları, programlar vb.) geliştirilmeli,

- Farklı beceri alanlarına yönelik çalışmalarda bulunmalı,

$1 \quad 6.7$

- Farklı ülkelerde yaşayan Türk çocukları üzerine çalışmalı,

$4 \quad 4.7$

- Yurt dışında yaşayan Türk çocukları hakkında yapılan çalışmaların sayısı artırılmalı,

$4 \quad 100$

3.6

133.3

$1 \quad 33.3$

$1 \quad 33.3$

$85 \quad 100$

Tablo 19'da yurt dışında yaşayan Türk çocukları üzerine yapılmış olan makalelerin önerileri başlıklar hâlinde sunulmuştur. Tablo 19 incelendiğinde araştırmalarda yapılan önerilerin toplam altı başlık altında toplandığı görülmektedir. Önerilerin en çok hükümetlere (\%35.2) yönelik olduğu ortaya çıkmıştır. Daha sonra önerilerin sırayla öğrencilere/ailelere (\%20), öğretmenlere (\%18.8), ders kitaplarına (\%17.6), kullanılan yöntemlere (\%4.7) ve araştırmacılara (\%3.6) yönelik olduğu belirlenmiştir. Hükümetlere yönelik en fazla önerilen madde ise iki dilli eğitim modellerinin/programlarının geliştirilmesi ve desteklenmesiyle (\%5.8) ilgili olduğu görülmektedir. Genel çerçeveye bakıldığında araştırmacıların en çok üzerinde durdukları önerinin ailenin bilinçlendirilmesi (\%11.8) olduğu görülmektedir.

Yurt dışında yaşayan Türk çocukları üzerine yapılan lisansüstü tezlerin öneri dağııımı Tablo 20 'de gösterilmiştir.

Tablo 20.

Yurt dışında yaşayan Türk çocukları üzerine yapılan lisansüstü tezlerin öneri dağııımı

\begin{tabular}{|c|c|c|}
\hline Öneriler & $f$ & $\%$ \\
\hline Hükümetlere Yönelik Öneriler & 78 & 37.5 \\
\hline - Dil-kültür ilişkisini destekleyen sosyal ve kültürel etkinlikler düzenlenmeli, & 9 & 4.3 \\
\hline Türkçe eğitimini sağlamak için gerekli mercilerle iş birliği yapılmalı, & 9 & 4.3 \\
\hline - Öğretmenler niteliklerini geliştirici hizmet içi eğitimlere tabi tutulmalı, & 8 & 3.8 \\
\hline $\begin{array}{l}\text { - Türkçe ve Türk kültürü dersinin haftalık süresi uzatılmalı ve zorunlu ders } \\
\text { haline getirilmeli, }\end{array}$ & 7 & 3.3 \\
\hline $\begin{array}{l}\text { - Okul öncesi öğretmenleri de yurt dışında görevlendirilmeli ve okul öncesi } \\
\text { eğitim desteklenmeli, }\end{array}$ & 4 & 1.9 \\
\hline - Nitelikli öğretmenler yetiştirilmeli, & 4 & 1.9 \\
\hline - Öğrencilerin konuşma pratikleri yapabilmeleri için materyaller geliştirilmeli, & 4 & 1.9 \\
\hline $\begin{array}{l}\text { - Ana dilini, iki dilliliği ve kültür derslerini kapsayacak şekilde eğitim } \\
\text { modelleri\programları oluşturulmalı, }\end{array}$ & 4 & 1.9 \\
\hline $\begin{array}{l}\text { - Dört dil becerisini geliştirmeye yönelik somut hedefler seçilmeli ve müfredat } \\
\text { buna göre düzenlenmeli, }\end{array}$ & 3 & 1.4 \\
\hline $\begin{array}{l}\text { - Türkçe ve Türk kültürü dersinden alınan notların öğrencilerin sınıf } \\
\text { geçmelerinde etkili olması sağlanmalı, }\end{array}$ & 3 & 1.4 \\
\hline • Türkçe öğrenmek ve kullanmak teşvik edilmeli, & 3 & 1.4 \\
\hline
\end{tabular}


- Türkçenin kullanıldığı ve geliştirildiği web sayfaları, bilgisayar oyunları ve uygulamalar üretilmeli,

- Türk kültürünü ve eğitim sistemini tanıtmalı,

- Ana dili ders programı ve kitapları güncellenmeli,

- Yurt dışında eğitim veren okul ve üniversitelere Edebiyat ve Türkçe Öğretimi bölümlerinden misafir öğretim üyeleri gönderilmeli.,

Türk çocuklarının sadece meslek ve teknik eğitim alanında yetişmelerinin önüne geçilmeli,

- İkinci dili desteklemek için hazırlık sınıfı oluşturulup öğrenciler bir yıl boyunca eğitimden geçirilmeli,

- Koordinatör öğretmenlerin getirilmesini sağlamalı,

- Kültürel ögelerin hangi etkinliklerle aktarılabileceği konusunda yol gösterilmeli,

- Kitaplar, yapılan çalışmalar göz önüne alınarak hazırlanmalı,

- Türkçe, bilim dili olarak geliştirilmeli,

- Türkçe ve Türk Kültürü dersi öğretmenlerinin 2 aşamalı sınav dışında bir de sözlü sınava tabi tutulmalı,

- Yurt dışına gönderilen öğretmen sayısı arttırılmalı,

- Türkçe kursları açılmalı,

- Ana dili öğretimi, ikinci dil öğretimi ve konu öğretimi ile koordine edilmeli,

- Uzaktan Türkçe ve Türk Kültürü dersleri verilmeli,

Öğretmene Yönelik Öneriler

- Öğrencilere dört temel dil becerisi etkili şekilde kazandırılmalı,

- Türkçenin kullanıldığı ve geliştirildiği ortamlar düzenlenmeli,

- Ana dili, ikinci dil ediniminde yardımcı olarak kullanılmalı,

- Yurt dışında eğitim veren öğretmenler iki dile de hâkim ise derslere girmeli,

- Kelime öğretimi çalışmaları için plan ve materyal hazırlanmalı,

- Öğrencilere verilen ödevler değerlendirilerek öğrencilere dönütler verilmeli,

- Öğrencilere dil öğrenmeye karşı olumlu tutumlar kazandırmalı,

- Öğrencilere iki dilli ve iki kültürlü olmanın bir eksiklik olmadığı kavratılarak özgüven aşılanmalı,

$40 \quad 19.2$

$9 \quad 4.3$

Türkçeyi iki dilli olarak öğrenen öğrenciler için her kura göre sesli okuma ölçekleri hazırlanmalı,

- Öğrencilere kalıp ifadeler, şarkılar ve tekerlemeler ezberlettirilmeli,

- Arapça ve Farsça kelimelerdeki uzun okunan sesler fark ettirilmeli ve üzerinde daha fazla durulmalı,

Her sınıf seviyesi için kelime sıklığı çalışması yapılmalı,

- Yetkili kişilerle iş birliği yapmalı, Kitaba/Materyale Yönelik Öneriler

- Kitaplarda kullanılacak metinler hedef kitlenin özellikleri dikkate alınarak seçilmeli,

- Süreli yayınlar oluşturulmalı ve takip edilmeli,

- Kitaplarda kullanılan metinler metinsellik ölçütleri bakımından değerlendirilmeli,

$34 \quad 16.3$

$5 \quad 2.4$

- Kullanılacak kitaplar, materyaller ve görseller öğrencilerin kendi anavatanındaki ve yaşadıkları ülkedeki kültürleri harmanlayacak şekilde 4 olmalı,

- Metinler millî ve evrensel değerlere uygun düzenlenmeli,

- Okullarda ders kitabının yanı sıra Türkçe okuma kitaplarına yer verilerek sayısı artırılmalı, 
- Kültürel ögeleri yeterince içermeli,

- Temel dil becerilerini kazandırabilmeli,

- Kullanılacak kitap ve materyaller genel kabul görmüş Avrupa Dilleri Öğretimi Çerçeve Programına göre düzenlenmeli,

- Türkçe ve Türk Kültürü dersinde kullanılan kitapların niteliği iyileştirilmeli ve ivedilikle güncellendirilmeli,

- Metinlerde dil ve anlatım kurallarına dikkat edilmeli,

- íki dilli kitaplar hazırlanmalı,

- Kültür aktarımını sağlayıcı nitelikte olmalı,

- Türkçenin zenginliklerini yansıtıcı olmalı,

- Metinler ve görseller estetik değer taşımalı,

- Öğrenciler ve aileler Türkçe öğrenimi ve kültürü konusunda bilinçlendirilmeli,

- Çocukların Türkçeye maruz kalacakları ortamlar oluşturmalı,

- Aileler çocuklarının dil gelişimi için yetkililerle iş birliği içinde olmalı,

- Anne ve babalar Türkçeyi doğru, güzel ve etkili şekilde kullanıp çocuklarına model olmalı,

- Aile desteği sağlanmalı,

- Aileler çocuklarının dil gelişimini destekleyici faaliyetlerde bulunmalı,

- Türkçeyi doğru, güzel ve etkili kullanma amacıyla ailelere ve öğrencilere yönelik diksiyon eğitimi verilmeli,

$33 \quad 15.8$

$12 \quad 5.7$

Öğrenciler sosyal faaliyetlere katılarak kendilerini geliştirmeli, $\quad \begin{array}{lll}1 & 0.4\end{array}$

- Iki dilli ailelerde her ebeveyn kendi dili ile konuşmalı,

- Türkçe öğretimi ders dışı aktivitelerle desteklenmeli,

- Öğrenciler, çeşitli materyallerle (kitap, dergi, müzik vb.) Türkçe gelişimini desteklemeli,

- Dil becerilerini geliştirici ve gerçek hayatta dil öğrenmelerine benzer şekilde

etkinlikler (oyunlar, bilgisayar programları vb.) geliştirilmeli,

12

$4 \quad 1.9$

- Öğrencilerin kendilerini izlemelerine fırsat verici ve motive edici öğretim stratejileri kullanılmalı,

- Sesli okuma becerilerini geliştirmek için çeşitli yöntem ve teknikler kullanılmalı,

- Öğrencilerin seviyesine uygun olan gazete, dergi gibi güncel yayınlar derslerde kullanilmalı,

- Sesli okumanın dinleme, konuşma gibi becerilerle bağlantısı kurulmalı,

- Melodik, aksan ve ritim kalıpları, mesajın anlamının aktarımını kolaylaştırdığı için öğrencilere farklı ritimlerin taklidi yaptırılmalı,

- Türkçe eğitimindeki sorunlar, yöntem ve teknikler gözden geçirilmeli,

Araştırmacıya Yönelik Öneriler

- Araştırmaların sonucunda oluşturulan ölçekler diğer çalışmalarda kullanılıp geliştirilmeli,

- Yöntem ve tekniğe yönelik çalışmalara daha çok yer verilmeli,

- Farklı ülkelerde yaşayan Türk çocukları üzerine çalışmalar yürütülmeli,

- Yurt dışında yaşayan Türk çocuklarının dil kazanımlarını ölçecek yeni ölçme araçları geliştirilmeli,

- Yapılan çalışmalar gerek örneklem gerekse süre bakımından genişletilmeli,

$1 \quad 0.4$

$11 \quad 5.2$

- Türkçe ve Türk Kültürü ders kitaplarını kültürel açıdan inceleyen çalışmalar yapılmalı,

$4 \quad 1.9$

$\begin{array}{ll}2 & 0.9\end{array}$

$2 \quad 0.9$

$\begin{array}{ll}1 & 0.4\end{array}$

$\begin{array}{ll}1 & 0.4\end{array}$

$\begin{array}{ll}1 & 0.4\end{array}$

Toplam

208

100


Tablo 20'de yurt dışında yaşayan Türk çocukları üzerine yapılmış olan lisansüstü tezlerinin önerileri başlıklar hâlinde sunulmuştur. Tablo 20 incelendiğinde araştırmacıların en fazla hükümetlere yönelik önerilerde (\%37.5) bulundukları görülmektedir. Daha sonra sırayla öğretmenlere (\%19.2), kitaplara/materyallere (\%16.3), öğrenciye/aileye (\%15.8), kullanılan yöntemlere (\%5.7) ve araştırmacılara (\%5.2) yönelik önerilerde bulunulmuştur. Hükümetlere en fazla önerilen maddeler ise dil-kültür ilişkisini geliştiren sosyal ve kültürel etkinliklerin düzenlenmesi ve Türkçe eğitimini sağlamak için gerekli mercilerle iş birliği yapılması (\%6.1) ile ilgilidir. Genel çerçeveye bakıldığında araştırmacıların en çok üzerinde durdukları önerinin ailenin Türkçe öğrenimi ve kültür aktarımı konusunda bilinçlendirilmesi (\%5.7) olduğu görülmektedir.

\section{Tartışma, Sonuç ve Öneriler}

Bu çalışmada, yurt dışında yaşayan Türk çocuklarını dil açısından ele alan tezler ve makaleler içerik analizi yapılarak incelenmiştir. Araştırma yapılırken çalışmalar; yayın yılına, anahtar kelimelerine, araştırmanın konusuna, örneklemine, yapıldığı ülkeye, yöntemine, veri toplama araçlarına, sonuçlarına ve önerilerine göre tez ve makale için ayrı ayrı tablolaştırılmıştır.

2000-2018 yıllarını kapsayan yaklaşık 20 yıllık bir dönemde yapılan yüksek lisans tezi, doktora tezi ve makalelerin taranmasına rağmen toplamda 37 çalışmanın bulunması araştırma konusu ile ilgili çalışmaların yeterli sayıda olmadığını göstermektedir. 2015 yılından sonra makale ve tezlerin sayısında genel olarak bir artış olduğu görülmektedir. Araştırmaların son 5 yılda hız kazanmış olması ise konu üzerine çalışmalar yapmaya başlayan akademisyenlerin sayısının arttığını ve konunun son yıllarda dikkat çekmeye başladığını göstermektedir. Bunun göstergeleri olarak 2010 yılında faaliyete geçen Yurtdışı Türkler ve Akraba Toplulukları Başkanlığı ile 2018 yılında çeşitli üniversiteler bünyesinde açılmaya başlanan Yurt Dışındaki Türk Çocuklarına Türkçe Öğretimi Tezli Yüksek Lisans Programları sayılabilir (http2).

Makalelerde toplamda 83 kere kullanılmış olan 62 tane ve tezlerde ise toplamda 73 kere kullanılmıs olan 57 tane farklı anahtar kelimenin olduğu sonucuna ulaşılmıştır. Ancak bu anahtar kelimelerden bazılarının aynı manaya gelmesine rağmen farklı adlandırmalarla ifade edildikleri ve kullanıldıkları görülmüştür. Bu durum araştırma alanının yeniliği ve genişliğinden kaynaklanıyor olabileceği gibi henüz terimlerle ilgili ortak bir paydada birleşilemediğinin göstergesi olarak da yorumlanabilir. Çalışmalarda en çok kullanılan anahtar kelimeler iki dillilik ve ana dili kavramlarıdır. Bunun sebebi ise çalışmaların daha çok yurt dışında yaşayan Türk çocuklarının ana diline ve iki dilliliklerine dair durumlarının tespit edilmesine yoğunlaşmasından kaynaklandığı düşünülmektedir.

Ele aldıkları konular açısından çalışmalar incelendiğinde araştırmacıların dil becerilerine daha çok yoğunlaştıkları görülmüştür. Dil becerilerinde yazma ve okuma ağırlıklı araştırmalar yapılırken konuşma ve dinleme becerilerinin ihmal edildiği sonucuna ulaşılmıştır. Dil becerilerinin geliştirilmesinde önemli bir etken olan yöntem-tekniği ve kitapları konu edinen çalışmaların az sayıda olması sorunları belirlemeye yönelik bir çaba olsa da çözüm aşamasında yol gösterici ve yardım edici araştırmaların yeterince bulunmadığını göstermektedir. Dil becerilerinden sonra en çok ele alınan konunun ise kültür ve kültür aktarımı olması dilin kültürün taşıyıcısı olması ve bir dili öğrenmenin bir kültürü öğrenmek anlamına geliyor olmasından kaynaklandığı söylenebilir. Çelebi'nin (2006) de belirttiği gibi "Anadili bir ulusun kimliğini, kültürünü ve benliğini yansıtan bir araçtır". Bu bağlamda ailelerin ve hükümetin dil aracılığıyla Türk kültürünü yaşatmaya çalışığı, kendi dil ve kültürlerinden uzakta yaşayan Türk çocuklarının karşılaştıkları sorunların önüne geçmeye yönelik çabaları olduğu söylenebilir. Tekin'in (2015) ve Arı'nın (2015) çalışmalarında da bu konu üzerinde durulmuş, ana dilini öğrenmenin kültürel yönden gelişime faydalı olacağı belirtilmiştir.

Hem tezlerde hem de makalelerde seçilen örneklemlerin yarısından fazlasını öğrencilerin oluşturması dikkate değer bir bulgudur. Buna göre, araştırmacıların doğrudan öğrenciden bilgi edinmeyi tercih ettikleri söylenebilir. Dil becerilerinin ölçülmesinde ve eğitimin her kademesinde odakta olan öğrencilerin, araştırmada veri elde etme kaynağı olarak daha çok tercih edilmesi de kaçınılmazdır. Yurt dışında yaşayan Türk çocuklarının çalışmalarda örneklem olarak daha fazla seçilmiş olmasının nedeni araştırmacıların teorik çalışmalar yerine pratikteki uygulamaları daha fazla tercih ettiklerini ve hedef kitleyle doğrudan etkileşim kurabilecekleri araştırmalara yöneldiklerini 
göstermektedir. Makalelerde en az çalışılan örneklem proje ve programlar iken kitaplara yönelik herhangi bir çalışma yapılmamıştır. Kitaplara yönelik bir çalışmanın bulunmaması dersin ana kaynağını teşkil eden bu materyallerin içeriğinin yeterince incelenmediğini ve gelişen şartlar yönünden iyileştirilmediğini göstermektedir. İnce'nin (2011) çalışmasına göre Türkçe ve Türk Kültürü ders kitapları 2010 yılında hazırlanmış ve kullanılmaya başlanmıştır. Ayrıca bu kitaplar tek dilli öğrencilere göre hazırlanmış ve seviyeye uygun olmayan metinler içermektedir. Şahin'in (2015) yaptığı çalışmada kitaptaki metinlerde bağdaşıklık ve tutarlılık açısından bir soruna rastlanmadığı, görsellerin düzeye uygun olduğu, atasözü ve özdeyişlerin kullanıldığı sonucuna ulaşımasının yanı sıra metinlerin eğitici ve kısa olmaması yönünden eleştirmesi dikkat çekmektedir. Bu çalışmalar, sonucu desteklemekte ve kitapların hangi yönlerden eksik olduğunu ortaya koyarak yapılması gereken düzenlemeleri göstermektedir.

Hem tezlerin hem de makalelerin yapıldığı ülkelere bakıldığında Almanya ve Fransa'nın önde olduğu görülmektedir. Bu durum göç eden Türklerin genellikle Batı Avrupa ülkelerine yerleşmiş oldukları bilgisiyle uyum göstermektedir. Almanya ve Fransa'nın ilk sıralarda olması ise Tüik'ten elde edilen verilerle açıklanabilmektedir. Bu verilere göre Almanya'da 1.629.480 Türk, Fransa'da ise 459.611 Türk yaşamaktadır. Buna göre Türk çocukları üzerine yapılan araştırmaların bu iki ülkede yoğunlaşmıs olması kaçınılmazdır.

Makaleler ve tezler incelendiğinde araştırmacıların çalışmalarını çoğunlukla nitel yöntemlere göre yürüttüğü görülmektedir. Bu durumun Türk nüfusunun farklı ülkelerde dağınık şekilde yaşıyor olması sebebiyle araştırmacıların tek seferde çok sayıda kişiye ulaşamaması bu çalışmaları nicel yöntemle yürütmenin zor olmasından kaynaklandığı şeklinde yorumlanabilir. Bir başka sebep de özellikle dil becerilerinin ölçülmesinde ve değerlendirilmesinde nitel yöntemlerin nicel yöntemlere kıyasla daha ayrıntılı veriler sağlıyor olması şeklinde değerlendirilebilir. İnce'nin (2011) yurt dışındaki Türk çocuklarının ana dilleri Türkçede yaşadıkları anlatım sorunları üzerine yaptığı çalışma, Ustabulut'un (2014) sesli okuma hataları üzerine yaptığı araştırma, Bilgiç'in (2016) yazılı kelime sıkıılarını araştırdığı çalışma ve Aydın ile Gün'ün (2018) sözlü dil becerilerindeki yanlışları araştırdığı çalışma da nitel yönteme göre yürütülen çalışmalara örnek olarak gösterilebilir. Araştırmaya dâhil edilen çalışmalardan tezlerin ikisinde, makalelerin ise üçünde yöntem bölümü veya bilgisi olmaması bu çalışmaların genel kabul görmüş formatta düzenlenmediğini göstermektedir. Bu durum araştırmacıların yöntem kısmına fazla ilgi göstermemelerinden veya yöntem konusunda yeterli bilgiye sahip olmamalarından kaynaklanabilir. Tezlerde de makalelerde olduğu gibi nitel yöntemin ön plana çıkmasının sebebi olarak az örneklem ile çok veri elde etmenin amaçlanması söylenebilir. Ayrıca yurt dışında yaşayan Türk çocuklarından fazla sayıda kişiye tek seferde ulaşılabilmesinin mümkün olmaması araştırmacıları nitel çalışmalara yönlendirdiği şeklinde düşünülebilir.

Makalelerde ve lisansüstü tezlerinde en çok kullanılan veri toplama aracı anket/ölçektir. Anketin/ölçeğin diğer veri toplama tekniklerine göre farklı bölgelerden çok daha büyük gruplara hızla uygulama olanağının olması ve maliyetinin daha düşük olması daha çok kullanılmasına sebep olabilir. Makalelerde en az tercih edilen veri toplama aracı ise öğrencilerden elde edilen dokümanlardır. Uygulamanın zor olması ve değerlendirmenin zaman alması bu durumun sebebi olarak gösterilebilir. Lisansüstü tezlerinde en az tercih edilen veri toplama aracı ise görüşme formlarıdır. Yetkili mercilerden gerekli izinlerin alınması, kişilere ulaşmada sorun yaşanması, objektif ve doğru veriler elde edilmesinin zor olması gibi nedenlerden ötürü bu veri toplama aracı daha az kullanılmıştır.

Çalışmaların sonuçları incelendiğinde makalelerde en fazla ailelerin demografik özelliklerinin, dil tercihlerinin ve dil öğrenmeye karşı tutumlarının çocukların dil becerilerini etkilediği sonucuna ulaşıımıştır. Anne ve babanın yaşı, gelir düzeyi, mesleği, eğitim seviyesi, etnisitesi, yurt dışında kalma süresi, kullanılan baskın dil, Türkçeye ve Türkçe öğrenmeye karşı tutumları öğrencinin dil becerilerini etkilemektedir. Parlak'ın (2014) çalışmasına göre ailelerin dil tercihinin bulundukları toplumun baskın dilinden yana olması çocukta ana dilsel kayıplara yol açmakta ve ana dili eğitimini geri plana atmaktadır. Lisansüstü tezlerde ise en fazla ortaya çıkan sonuç öz düzenleyici öğrenme stratejilerinin dil becerilerinin gelişimini etkilediğine yöneliktir. Çelik'in (2016) çalışmasına göre yurt dışında yaşayan Türk çocuklarına yönelik olarak öz düzenleyici öğrenme stratejileriyle gerçekleştirilen Türkçe 
öğretiminin çocukların ana dili becerilerini ve ana diline karşı tutumlarını olumlu yönde etkilemesi bu sonucu destekler niteliktedir.

Çalışmalarda yapılan öneriler analize tâbi tutulduğunda hükümetlere yönelik önerilerin çoğunlukta olduğu sonucuna ulaşılmıştır. Genel çerçeveye bakıldığında makalelerde ve tezlerde ailenin Türkçe öğretimi ve Türk kültürü konusunda bilinçlendirilmesi öne çıkmaktadır. Çünkü çocuğun dilsel ve kültürel gelişimi içine doğduğu aile ortamında başlayıp okulda devam eden bir seyir izlemektedir (Özbay, 2016). Bu yüzden ana dili eğitimi konusunda ailelerin bilinçlendirilmesi önerisinin ön plana çıkması kaçınılmazdır. Damar'ın (2007) ve Şen'in (2011) de çalışmalarında dil konusunda ailenin bilinçlendirilmesi üzerinde durmuş olması bu sonucu destekler niteliktedir. Makalelerde ve lisansüstü tezlerde en az öneriler araştırmacılara yönelik olanlardır. Böyle bir sonuca ulaşııması gelecekte yapılacak araştırmalar için araştırmacılara yol gösteren nitelikte önerilerde bulunulmadığını ortaya çıkarmaktadır.

Araştırma bulguları incelendiğinde ortaya çıkan sonuçlara bakılarak şu önerilerde bulunulabilir:

Aileye Yönelik Öneriler

- Aileler Türkçe ve Türk kültürü konusunda bilinçlendirilmeli.

- Aileler, Türkçenin doğru ve güzel kullanımı konusunda model olmalı.

- Aileler, çocuklarına Türkçeyle etkileşime girecekleri ortamlar sağlamalı. Hükümete Yönelik Öneriler

- Türkçe ve Türk Kültürü dersine yönelik kitaplar ve materyaller geliştirilmeli.

- Yurt dışında yaşayan Türk çocuklarına yönelik sosyal ve kültürel etkinlikler düzenlenerek Türkçe ve Türk kültürü tanıtılmalı.

- Yurt dışındaki Türk çocuklarının öğretmen ihtiyacını karşılayabilmek ve nitelikli öğretmenler yetiştirebilmek için yüksek öğretimde alana yönelik programlar açılmalı.

- iki dile ve iki kültüre hâkim eğitimciler yetiştirilmeli.

- Aile, öğrenci, ilgili kurumlar ve hükümet arasında kuvvetli iş birliği sağlanmalı.

Araştırmacılara Yönelik Öneriler

- Literatürdeki araştırmalar toparlanarak ortak bir terim sözlüğü oluşturulmalı.

- Belli başlı ülkelerde yapılan çalışmalar farklı ülkelerde yaşayan Türk çocuklarına da yapılmalıdır.

- Araştırmaların örneklem ve süre bakımından genişletilerek sonuçların genellenebilirliği arttırılmalı.

- Araştırmacıların bu alana yönelmeleri desteklenmeli ve araştırmaları sırasında kolaylıklar sağlanmalı.

- Yurt dışında yaşayan Türk çocuklarının dil kazanımlarını ölçecek yeni ölçme araçları geliştirilmeli.

- Araştırmaların daha nitelikli olması adına araştırmacılar yöntem konusunda kendilerini geliştirmelidir.

- Daha geçerli ve güvenilir veriler elde etmek için farklı veri toplama araçlarından faydalanılmalı.

\section{Kaynaklar}

Achmet, i. K. (2005). Yunanistan'da (Batı Trakya'da) ikidilli Eğitim Veren Okullarında Türkçe ve Yunanca Eğitim Gören Öğrencilerin Okuduğunu Anlama ve Yazılı Anlatım Becerilerinin Değerlendirilmesi. (Yayımlanmamış Doktora Tezi). Ankara Üniversitesi Sosyal Bilimler Enstitüsü, Ankara.

Aksan, D. (2009). Her Yönüyle Dil. Ankara: Türk Dil Kurumu.

Aksan, D. (2014). Her Yönüyle Dil, Ana Çizgileriyle Dilbilim 1. Ankara: TDK Basımevi.

Arı, G. T. (2015). iki Dilli Türk Çocuklarının ve Velilerinin Ana Dili Türkçeyi Öğrenme Tutumları (Aisne Bölgesi- Fransa Örneği). (Yayımlanmamış Yüksek Lisans Tezi). Gazi Üniversitesi Eğitim Bilimleri Enstitüsü, Ankara. 
Aydın, G. ve Gün, M. (2018). Çok Uluslu Aileye Sahip iki Dilli Çocukların Türkçe Sözlü Dil Becerilerinin YanlışÇözümleme Yöntemine Göre İncelenmesi. Ana Dili Eğitimi Dergisi, 6(2), 325-342.

Baker, C. (1988). Key Issues in Bilingualism and Bilingual Education. Clevedon: Multilingual Matters.

Baker, C. ve Jones, S. P. (1998). Encyclopedia of Bilingualism and Bilingual Education. UK: Multilingual Matters.

Baker, C. (2007). A Parents' and Teachers' Guide to Bilingualism (3th Edition). Clevedon: Multilingual Matters.

Baker, C. (2011) Foundations of Bilingual Education and Bilingualism. Clevedon: Multilingual Matters. Başkan, Ö. (2003). Bildirişim Insan-dili ve Ötesi. İstanbul: Multilingual.

Bhaita, T. K. ve Ritchie, W. C. (2006). TheHand book of Bilingualism. UK: Blackwell Publishing.

Bilgiç, M. (2016). Batı Avrupa'da iki Dilli Türk Çocuklarının Yazılı Türkçe Kelime Sıklıkları Fransa Örneği. (Yayımlanmamış Yüksek Lisans Tezi). Sakarya Üniversitesi Eğitim Bilimleri Enstitüsü, Sakarya.

Bingöl Arslangilay, A. S. (2013). 3. Kuşak Türk Çocukları ve iki Dilli-iki Kültürlü Eğitim Modelleri (Hessen Eyaleti Koala Projesi). (Yayımlanmamış Doktora Tezi). Gazi Üniversitesi Eğitim Bilimleri Enstitüsü, Ankara.

Çelebi, M.D. (2006). Türkiye'de Anadili Eğitimi ve Yabancı Dil Öğretimi. Erciyes Üniversitesi Eğitim Fakültesi Sosyal Bilimler Enstitüsü Dergisi, 21, 285.

Çelik, M. E. (2016). Bulgaristan'daki Türkçe Öğretmenlerinin Türkçenin Eğitimi-Öğretimine iliş̧in Görüşlerinin İncelenmesi. Ondokuz Mayıs Üniversitesi Eğitim Fakültesi Dergisi, 35(2), 69-81.

Damar, M. (2007). İsviçre'de Yaşayan Altı Yaş Türk Çocuklarının Dil Kazanımlarına Yönelik Geliştirilen Türkçe Dili Etkinlikleri Gözlem Formu Geçerlilik ve Güvenirlik Çalışması. (Yayımlanmamış Doktora Tezi). Gazi Üniversitesi Eğitim Bilimleri Enstitüsü, Ankara.

Ekiz, D. (2017). Bilimsel Araştırma Yöntemleri (5. Baskı). Ankara: Anı Yayınclık.

Field, F. W. (2011). Key Concepts in Bilingualism. New York: Palgrave Macmillan.

Ince, B. (2011). Yurt Dışındaki Türk Çocuklarının Anadilleri Türkçede Yaşadıkları Anlatım Sorunları Fransa Örneği. (Yayımlanmamış Doktora Tezi). İstanbul Üniversitesi Sosyal Bilimler Enstitüsü, İstanbul.

Kırımlı, B. (2006). Türkiye'de Ana Dili Eğitimi ve Ana Dilinde Eğitimle IIlgili Görüşler Üzerine Bir Çalışma. TurkishStudies, 12,231-256.

Ögel Horny, S. (2011). Migrationsbedingte Muttersprachliche Defizite Türkischer Kinder In Deutschland Eine Empirische Untersuchung in Tübingen. (Yayımlanmamış Yüksek Lisans Tezi). Anadolu Üniversitesi Eğitim Bilimleri Enstitüsü, Eskişehir.

Özbay, M. (2016). Türkçe Özel Öğretim Yöntemleri I. Ankara: Öncü Basımevi.

Parlak, H. (2014). Avustralya'daki Türk Ailelerin Ana Dil Edinimi Üzerindeki Rolü. Sosyal Politika Çalışmaları Dergisi, 32, 9-31.

Şahin, A. (2015). Yurt Dışındaki Türk Çocukları Için Hazırlanmış Olan Pilot (5. Sınıf) Ders Kitabının Metinsellik Ölçütleri Bağlamında Çözümlenmesi. (Yayımlanmamış Yüksek Lisans Tezi). Gazi Üniversitesi Eğitim Bilimleri Enstitüsü, Ankara.

Şen, Ü. (2011). Belçika'da Yaşayan Türk Çocuklarının Türkçeye Yönelik Tutumları ve Yazma Becerileri. (Yayımlanmamış Doktora Tezi). Gazi Üniversitesi Eğitim Bilimleri Enstitüsü, Ankara.

Şen, Ü. (2016). Belçika'da Yaşayan Türk Çocuklarının Yazıı Anlatım Yanlışları Üzerine Tespitler. Mustafa Kemal Üniversitesi Sosyal Bilimler Enstitüsü Dergisi, 13(35), 1-18.

Tekin, N. M. (2015). Ingiltere'deki Ana Dili Türkçe Olan Öğrencilerin Türkçe Dersine Yönelik Tutumları. (Yayımlanmamış Yüksek Lisans Tezi). Gazi Üniversitesi Eğitim Bilimleri Enstitüsü, Ankara.

Tüik (2018). Türkiye Istatistik Kurumu.

Türk Dil Kurumu. (2011). Türkçe Sözlük. Ankara: TDK.

Ustabulut, M. Y. (2014). iki Dilli Türk Çocuklarına Türkiye Türkçesi Öğretiminde Sesli Okuma Hataları ve Bu Hataların Düzeltilmesi İçin Yapılabilecek Yöntem ve Teknikler Romanya Örneği. (Yayımlanmamış Yüksek Lisans Tezi). Gazi Üniversitesi Eğitim Bilimleri Enstitüsü, Ankara.

Vardar, B. (1988). Açıklamalı Dilbilim Terimleri Sözlügü. İstanbul: ABC Tanıtım Basımevi.

Yıldırım, A. ve Şimşek, H. (2011). Sosyal Bilimlerde Nitel Araştırma Yöntemleri. Ankara: Seçkin Yayıncilık. 
Yılmaz, M. Y. (2014). Iki Dillilik Olgusu ve Almanya'daki Türklerin iki Dilli Eğitim Sorunu. TurkishStudies,9, 1641-1651.

http1 - http://www.hurriyet.com.tr/en-fazla-turk-almanyada-yasiyor-40880003 adresinden 04.07.2019 tarihinde elde edilmiştir.

http2 - http://www.tyb.com.tr adresinden 05.07.2019 tarihinde elde edilmiştir.

\section{Extended Abstract Introduction}

Mother tongue which is discussed in psychological, sociological, ethnic and political contexts in addition to education and acquired in social environments is defined in different ways. According to Aksan (2014), mother tongue is the language which is learned from the mother and in the immediate family environment at the beginning, then in the larger environment, which penetrates into the human subconscious and constitutes the strongest connections of the individual with the society he lives in. Today, however, individuals have to learn different languages in the language acquisition process in which they start learning their mother tongue and the native language of the country they live in and they eventually become bilingual. Bilingualism is on the increase in countries, especially due to the major events that shape the world (wars, mass migration, international country unions such as the European Union) and the preferences of individuals such as education, marriage, individual migration (Şen,2016). Bilingualism is a term used to identify individuals having or speaking two or more languages. Throughout history, the children of Turkish families who migrated abroad for various reasons have been exposed to a language other than their mother tongue and became bilingual. The aim of this study is to make content analysis of the studies conducted between the years 2000-2018 intended for Turkish children living abroad and to determine the research trends.

\section{Method}

The study is qualitative and the data were collected through document analysis. The investigation results showed that there were 37 studies made between the years 2000-2018, 19 of which were published articles in journals in the TR-Index and 18 of which were available in the Higher Education Council National Thesis and Dissertation Center - 9 Master's theses and 9 doctoral dissertations. The articles and theses were analyzed in terms of their years of publication, keywords, subjects, samples, countries, method, data collection tools, results, and recommendations. It was found that there were very few studies on the subject. It was determined that most of the studies focused on Turkish children living in European countries in which there were dense Turkish populations and that the mostly preferred keywords were mother tongue and bilingualism. It was also found that the studies generally focused on language.

\section{Result and Discussion}

The results showed that there were very few studies on the subject. It was found that after 2015 the number of studies increased. The results showed that most of the studies focused on Turkish children living abroad. The countries in which the studies were generally conducted were Germany and France. 62 keywords were used in the articles and the number of keywords in the theses and dissertations was 57. Most common keywords in both articles and theses and dissertations were bilingualism and mother tongue.

The results showed that both articles and theses and dissertations were qualitative in design. This may be explained by the fact that it was hard to use the quantitative method because of the difficulty of reaching many people at once because Turks live in different countries. When the studies were examined in terms of their subjects, it was concluded that the researchers focused on language skills. It was also found that culture and culture transfer were the secondarily mostly investigated subjects.

When the results were examined, it was found that the mostly used data collection tool was questionnaire. It was also found that the least used data collection tool in the articles was documents obtained from the students; in theses and dissertations it was interview forms. It was concluded that 
the most common result was that the demographic characteristics such as parents' age, income level, profession, education level, ethnicity, duration of living abroad, dominant language used, language preferences and attitudes towards language learning of the families affected children's language skills. When the postgraduate theses were examined, it was concluded that the most common result was that self-regulation strategies affected language skills positively. When the recommendations of the studies were examined, it was found that the most common recommendations were made for governments and the least for researchers. In general, it was seen that most of the recommendations were made to raise awareness of families about Turkish and Turkish education. In conclusion, it may be stated that language is a social entity and the role of the family in language education is important. 